\title{
Applications of bioactive compounds extracted from olive industry wastes: A review
}

\author{
Joana Madureira ${ }^{1,2,3}$ \\ Isabel C. F. R. Ferreira ${ }^{2}$ \\ Fernanda M. A. Margaça ${ }^{1}$ \\ Sandra Cabo Verde ${ }^{1}$ \\ Celestino Santos-Buelga ${ }^{3,4}$ \\ Lillian Barros ${ }^{2}$ (1)
}

${ }^{1}$ Centro de Ciências e Tecnologias Nucleares (C2TN), Instituto Superior Técnico, Universidade de Lisboa, Loures, Portugal

${ }^{2}$ Centro de Investigação de Montanha (CIMO), Instituto Politécnico de Bragança, Campus de Santa Apolónia, Bragança, Portugal

${ }^{3}$ Grupo de Investigación en Polifenoles (GIP-USAL), Facultad de Farmacia, Universidad de Salamanca, Campus Miguel de Unamuno s /n, Salamanca, Spain

${ }^{4}$ Unidad de Excelencia Producción, Agrícola y Medioambiente (AGRIENVIRONMENT), Parque Científico, Universidad de Salamanca, Salamanca, Spain

\section{Correspondence}

Sandra Cabo Verde, Centro de Ciências e Tecnologias Nucleares (C2TN), Instituto Superior Técnico, Universidade de Lisboa, E.N. 10 ao km 139.7, 2695-066 Bobadela LRS, Portugal.

Email: sandracv@ctn.tecnico.ulisboa.pt Lillian Barros, Centro de Investigação de Montanha (CIMO), Instituto Politécnico de Bragança, Campus de Santa Apolónia, Bragança 5300-253, Portugal.

Email:lillian@ipb.pt

\begin{abstract}
The wastes generated during the olive oil extraction process, even if presenting a negative impact for the environment, contain several bioactive compounds that have considerable health benefits. After suitable extraction and purification, these compounds can be used as food antioxidants or as active ingredients in nutraceutical and cosmetic products due to their interesting technological and pharmaceutical properties. The aim of this review, after presenting general applications of the different types of wastes generated from this industry, is to focus on the olive pomace produced by the two-phase system and to explore the challenging applications of the main individual compounds present in this waste. Hydroxytyrosol, tyrosol, oleuropein, oleuropein aglycone, and verbascoside are the most abundant bioactive compounds present in olive pomace. Besides their antioxidant activity, these compounds also demonstrated other biological properties such as antimicrobial, anticancer, or anti-inflammatory, thus being used in formulations to produce pharmaceutical and cosmetic products or in the fortification of food. Nevertheless, it is mandatory to involve both industries and researchers to create strategies to valorize these byproducts while maintaining environmental sustainability.
\end{abstract}

KEYWORDS

bioactive compounds, cosmetics, food fortification, olive wastes, pharmaceuticals

\section{1 | INTRODUCTION}

In the Mediterranean region, mainly in countries such as Spain, Italy, Portugal, Greece, Syria, Morocco, and Tunisia, the olive oil production is one of the most important industries for their economy. European Union countries produce about $69 \%$ of the world's olive oil, being the leading producer, consumer, and exporter of this product. In the last years, other countries such as Argentina, Australia,
United States of America, and South Africa became olive oil producers (Dermeche et al., 2013; Roig et al., 2006) since the global consumption of olive oil has increased worldwide. As the olive oil benefits for human health are becoming widely recognized, the perspective is that of a continuous increase in its consumption (and consequent production) in the coming years.

The extraction of olive oil includes different processes such as olive washing, olive crushing, malaxing of the 


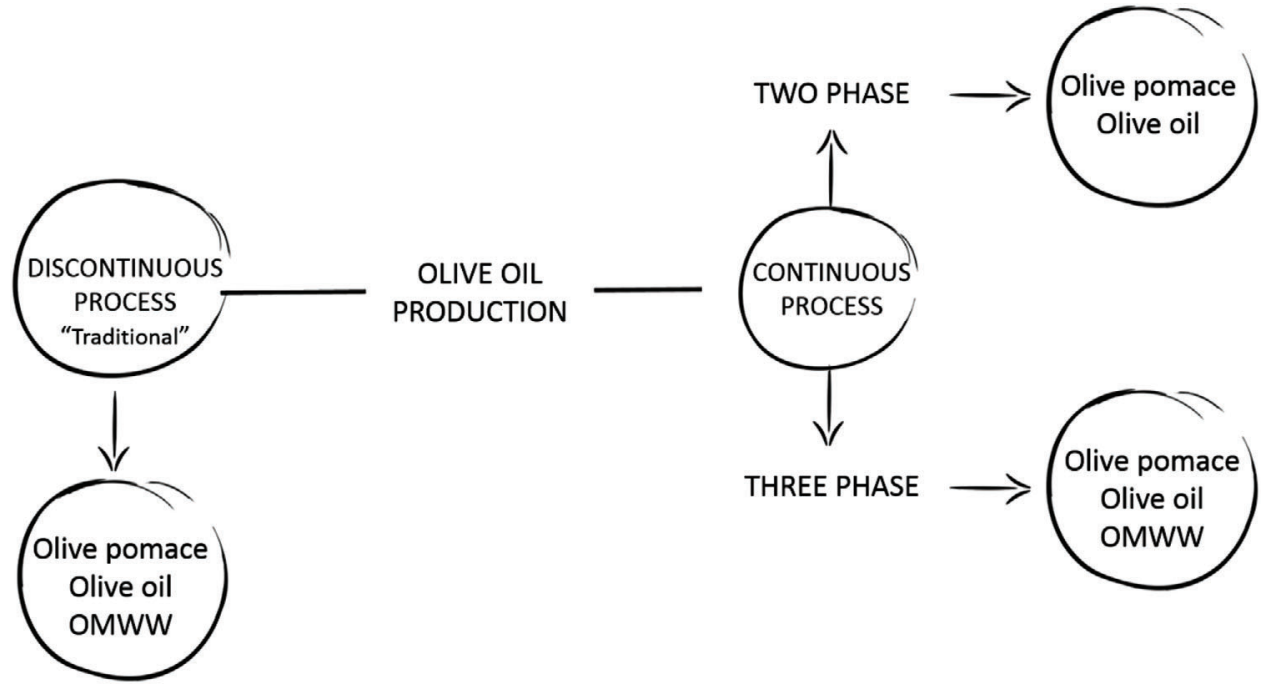

F I G U R E 1 Different processes for olive oil production. OMWW, olive mill wastewater. Adapted from Rodrigues et al. (2015)

resulting pastes and the extraction itself (Roig et al., 2006; Zbakh \& El Abbassi, 2012). The extraction of olive oil can be achieved through discontinuous (traditional pressing) or continuous (centrifugation) processes. Concerning the centrifugation processes, there are two possible systems, called three-phase and two-phase systems. In the threephase system, a solid cake and two liquids, olive oil and large amounts of an aqueous liquid known as olive mill wastewater (OMWW) are generated. In the two-phase system, less water is used during the process which means that the volume of OMWW produced is reduced in comparison with the other process. In this system, besides olive oil, a semisolid residue (wet pomace or olive pomace) constituted by olive husk and OMWW is generated (Caporaso et al., 2018; Rodrigues et al., 2015). Figure 1 summarizes the processes for olive oil extraction. The two-phase system is used in the modern units replacing the three-phase technology, in order to minimize the wastewater volume and energy requirements (Dermeche et al., 2013). In fact, Azbar et al. (2004) indicated that two-phase technology saves process water by $80 \%$ and energy up to $20 \%$. Nevertheless, its residues have a negative impact on the environment when they are discharged without treatment, due to their high toxicity and the resistance to biological degradation (AlKhatib et al., 2009; Fiorentino et al., 2003; Khdair et al., 2019; Pavlidou et al., 2014).

Although some papers are found describing the composition of olive wastes and their applications in different areas (Bhatnagar et al., 2014; Galanakis, 2018; Rodrigues et al., 2015), there is no review that evaluated and compiled the possible applications for each of its main bioactive compounds, individually. To our knowledge, the only review describing the use of hydroxytyrosol as a functional food ingredient, not only as pure compound but also in the form of hydroxytyrosol-rich extracts, was published by Silva et al. (2020). In the present review, the applications of the different wastes generated from the olive oil industry will be described. After that, the review will focus on the solid residue (olive pomace) produced by modern two-phase system. Phenolic characterization and quantification will be discussed and the challenging applications of the individual compounds will be carefully explored.

\section{2 | POTENTIAL APPLICATIONS OF OLIVE WASTES}

Regardless of its negative environmental impacts, the potential added value of olive wastes for numerous sectors is well known. In the literature, there are a few reviews reporting the different applications for olive wastes (Dermeche et al., 2013; Roig et al., 2006).

Olive wastes have been used as soil amendment, to increase soil fertility and organic carbon stored in the agro-systems (Federici et al., 2017; Majbar et al., 2018; Regni et al., 2017). Fernández-Hernández et al. (2014) observed amended soils with higher content of nitrogen, phosphorus, potassium, and organic matter than the soil treated with inorganic fertilizer when using olive wastes composts mixed with different agro-industrial wastes applied to an olive grove in Spain. The increase of soil fertility produced an increase in the olive oil content of the fruits (Fernández-Hernández et al., 2014), although other researchers considered that recycling these wastes could promote soil phytotoxicity, considerable decline in soil germination capability, and necrosis of the olive leaves (Arvanitoyannis \& Kassaveti, 2007). 
Olive wastes can also be used as biomass to produce renewable fuels (Tayeh et al., 2014; Al Afif \& Linke, 2019; Al-Addous et al., 2017; Messineo et al., 2020; Rincón et al., 2013; Romero-García et al., 2014; Serrano et al., 2017; Valenti et al., 2017). In a recent review paper, Messineo et al. (2020) reported the latest achievements in anaerobic digestion of olive mill residues in order to produce biofuels. In that review, the authors described not only the aspects of the process but also the existing pretreatments of olive wastes (Battista et al., 2016; Rincón et al., 2013; Siciliano et al., 2016) which are applied to induce the decomposition of the complex lignocellulosic structures before anaerobic digestion (Kumari \& Singh, 2018). Serrano et al. (2017) proposed a thermal pretreatment and a subsequent phenolic recovery before the anaerobic digestion step to improve methane production. Furthermore, some chemical and physical pretreatment methods, such as ultrasonic pretreatment, basic pretreatment with sodium hydroxide, calcium carbonate, and/or hydrogen peroxide were used to optimize hydrogen and bioethanol production from olive oil production residues (Battista et al., 2016; Siciliano et al., 2016).

Other way to valorize olive wastes is to convert them into inexpensive adsorbents for water pollution control (Anastopoulos et al., 2015), in particular, heavy metals (Abdelhadi et al., 2017; Fernández-González et al., 2019; Fernando et al., 2009; Martinez-Garcia et al., 2006; MartínLara et al., 2013; Pagnanelli et al., 2003). Martinez-Garcia et al. (2006) observed that olive wastes maintained their adsorptive capacity over 10 cycles. Moreover, the ability of these biosorbents to adsorb several metal ions may increase their potential application on industrial wastewater treatment (Abdelhadi et al., 2017; Martinez-Garcia et al., 2006).

Other interesting and valuable use of olive mill wastes is to replace fresh water in brick manufacturing which contributes to a reduction of the water consumption (De La Casa \& Castro, 2014; de la Casa et al., 2009; ElicheQuesada et al., 2014; Mekki et al., 2006; Mekki et al., 2008). Comparing their physical properties with control products using fresh water, promising results have been obtained showing a significant increase in the volume shrinkage $(10 \%)$ and the water absorption (12\%), while the tensile strength remained constant (Mekki et al., 2008). Similar results were observed by de la Casa et al. (2009) also with the improvement by $33 \%$ of the dry-bending strength when compared to the control bricks.

In order to contribute to a more sustainable food production, the wastes generated from olive industry can also be transformed into animal feed (Dunne, 2019; Estaún et al., 2014; Gerasopoulos, Stagos, Kokkas, et al., 2015; Gerasopoulos, Stagos, Petrotos, et al., 2015; Molina-Alcaide et al., 2010; Rojas-Cano et al., 2014), although it is neces- sary to pay attention to their digestibility, palatability, and safety (Rojas-Cano et al., 2014). Rojas-Cano et al. (2014) demonstrated that the inclusion of olive soap stocks in the diet of growing crossbred Iberian pigs did not affect the apparent digestibility of nutrients or body protein accretion but increased the energy value of the diet. Also, Serra et al. (2018) found that the swine diet was improved by the inclusion of olive wastes. Lipid oxidation slowed down in the sausages despite the higher and lower contents in polyunsaturated fatty acids (PUFAs) and saturated fatty acids, respectively, compared to the controls. In another study, it was observed that feed blocks containing olive pomace could improve the quality of milk compared with a conventional diet with no impact on the milk yield and reducing the feeding costs (Molina-Alcaide et al., 2010). Similarly, for broiler chickens, the use of olive wastes extracts was effective in reducing the oxidative stress and led to higher antioxidant capacity in plasma and tissues (Gerasopoulos, Stagos, Kokkas, et al., 2015).

With increasing consumer demand for healthier food, the industry and the scientific community started to produce new functional ingredients for food and beverages. The recent pandemic situation also affected the food sector, mainly food safety and security, becoming more important in the development of sustainable and modern food systems (Galanakis, 2020; Galanakis et al., 2021). Thereby, the supplementation of consumers' diets with bioactive ingredients (vitamins, peptides, polyphenols, and lipids) can be an important key for the prevention or recovery from COVID-19 disease (Galanakis et al., 2020). The addition of OMWW and olive paste, individually or combined, to bread and pasta was assessed by Cedola et al. (2020) and Simonato et al. (2019). The results demonstrated that the enrichment of bread and pasta with OMWW slightly improved the chemical quality without compromising the sensory properties, whereas the enrichment with olive paste considerably improved both phenolic contents and antioxidant activity although the sensory acceptability was worse due to its bitter and spicy taste. The combination of the two byproducts in the fortification of bread and spaghetti increased the whole quality index, being higher for bread (Cedola, Cardinali, et al., 2020). The fortification of wheat pasta with olive pomace also enhanced the dietary fiber of the final product, while increasing its firmness and decreasing its cooking time (Simonato et al., 2019). In other study, the bread and rusks fortified with olive polyphenols (200 mg of polyphenols $/ \mathrm{kg}$ ) demonstrated higher antimicrobial activity and extended their shelf life from 10 to 15 days (Galanakis et al., 2018). Moreover, the addition of olive leaf extracts to poultry meat decreased the microbial growth and maintained both chemical quality and sensory attributes (Saleh et al., 2020), thus extending the shelf life of the meat when refrigerated for 15 days. 
Olive byproducts are abundant sources of bioactive phenolic compounds (El-Abbassi et al., 2012; Madureira et al., 2020; Nunes et al., 2018; Yakhlef et al., 2018) that have promising potential as antioxidant, anti-inflammatory, and antimicrobial agents (Bulotta et al., 2014; Leouifoudi et al., 2014; Schaffer et al., 2010). Hence, the recovery of phenolic compounds from these wastes, after suitable purification, presents considerable interest for food and beverage (Araújo et al., 2015; Caporaso et al., 2018; Zbakh \& El Abbassi, 2012), cosmetic (Galanakis et al., 2018; Rodrigues et al., 2017; Rodrigues et al., 2015), and nutraceutical (Vitali Čepo et al., 2018) industries, due to their interesting pharmaceutical properties. In the last years, the extracted phenolic compounds have also been used to produce biodegradable packaging materials for various types of food products to replace the synthetic ones (de Moraes Crizel et al., 2018; Lammi et al., 2018). de Moraes Crizel et al. (2018) studied the incorporation of 30\% olive pomace flour in chitosan based films, protecting nuts against oxidation during 31 days. Lammi et al. (2018) developed biodegradable olive pomace-based fillers with lower stress and elongation at break and reducing costs.

\section{3 | BIOACTIVE COMPOUNDS EXTRACTED FROM OLIVE POMACE}

As previously discussed, in order to eliminate the OMWW generated in the three-phase system, the two-phase technology has emerged in the last 0 years, producing one major residue, olive pomace. Olive pomace comprises the olive husk and the OMWW, being one of the most polluting agricultural byproducts in the Mediterranean region (Papaioannou et al., 2013). Nevertheless, despite the very important polluting aspect, this waste contains high amounts of added value compounds, such as phenolic compounds, in variable amounts depending on several factors, such as olive variety and cultivar, harvest time, processing methods, and extraction process (Dermeche et al., 2013).

Cioffi et al. (2010) reported oleuropein $(81.7-83.9 \mathrm{mg} / \mathrm{kg}$ of dry weight) and ligstroside aglycone $(27.1-31.1 \mathrm{mg} / \mathrm{kg}$ of dry weight) as the most abundant compounds of olive pomace from Cilento National Park (Italy). In olive pomace from Algeria, oleuropein (144 mg/g of dry weight) was also detected as the major compound, and secoxyloganin $(55 \mathrm{mg} / \mathrm{g}$ of dry weight), loganin (47 mg/g of dry weight), and cyanidin-3-glucoside ( $39 \mathrm{mg} / \mathrm{g}$ of dry weight) were observed for the first time in olive wastes (Moudache et al., 2020). On the other hand, Madureira et al. (2020) described hydroxytyrosol ( $25 \mathrm{mg} / \mathrm{g}$ of extract) as the main phenolic compound present in olive pomace from the region of Alentejo (Portugal), followed by hydroxytyrosol-
1 - $\beta$-glucoside $(9.8 \mathrm{mg} / \mathrm{g}$ of extract) and tyrosol $(5.9 \mathrm{mg} / \mathrm{g}$ of extract), which is consistent with the observations made by Malapert et al. (2018). These authors also described hydroxytyrosol (370.7 mg/L), hydroxytyrosol glucoside $(165.2 \mathrm{mg} / \mathrm{L})$, and tyrosol (148.4 mg/L) as the major compounds present in olive pomace from Baux-de-Provence (France). Additionally, Nunes et al. (2018) observed that hydroxytyrosol and comsegoloside represented about $79 \%$ of the total phenolics present in olive pomace from the region of Trás-Os-Montes (Portugal). On the other hand, Rubio-Senent et al. (2012) observed high quantities of 3,4dihydroxyphenylglycol, elenolic acid derivatives, and comsegoloside besides hydroxytyrosol and tyrosol. Furthermore, verbascoside, gallic acid, caffeic acid, vanillic acid, oleuropein aglycone, $p$-coumaric acid, rutin, luteolin-7$\mathrm{O}$-rutinoside, and luteolin-7-O-glucoside were reported in lower amounts (Cioffi et al., 2010; Madureira et al., 2020; Malapert et al., 2018; Peralbo-Molina et al., 2012; RubioSenent et al., 2012).

Different methodologies for the extraction of these bioactive compounds from olive pomace can be performed using conventional and emerging technologies. Conventional techniques are based on solid-liquid extraction (Cardoso et al., 2005; Madureira et al., 2020; Suárez et al., 2009), but have some limitations namely long extraction times, high-energy dissipation, and low extraction selectivity and purity. In these ways, new and promising techniques were developed, such as ultrasound-assisted extraction (Goldsmith et al., 2018; Nunes et al., 2018), microwave-assisted extraction (Chanioti \& Tzia, 2018; Xie et al., 2019), pressurized liquid extraction (Pavez et al., 2019), and supercritical fluid extraction (Caballero et al., 2020) in order to improve the extraction yield of phenolic compounds from olive pomace.

Table 1 describes the main phenolic compounds found in olive pomace and their MS data.

\section{4 | APPLICATIONS OF THE MAIN BIOACTIVE COMPOUNDS EXTRACTED FROM OLIVE POMACE}

The possible applications of the bioactive compounds from olive pomace in different areas, after suitable purification, can be the focus of a sustainable valorization in innovative products. This contributes not only to enhance the sustainability of the olive sector, but also for economic and environmental aspects.

Figure 2 shows the chemical structures of the bioactive compounds discussed in this review. Table 2 summarizes the major compounds present in olive pomace and their health benefits, while Table 3 outlines the existing patents on applications of these compounds and Table 4 the 

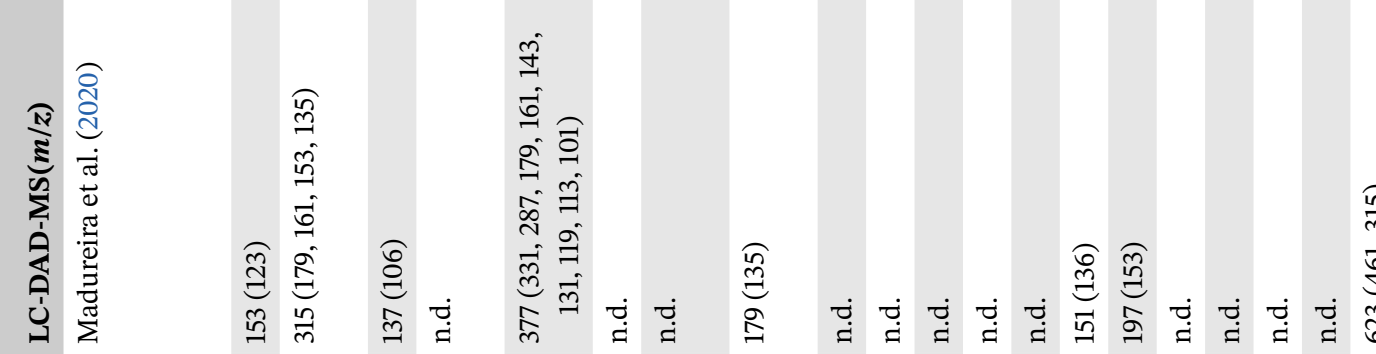

வ் घं

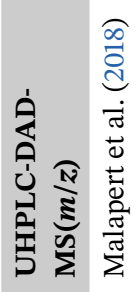
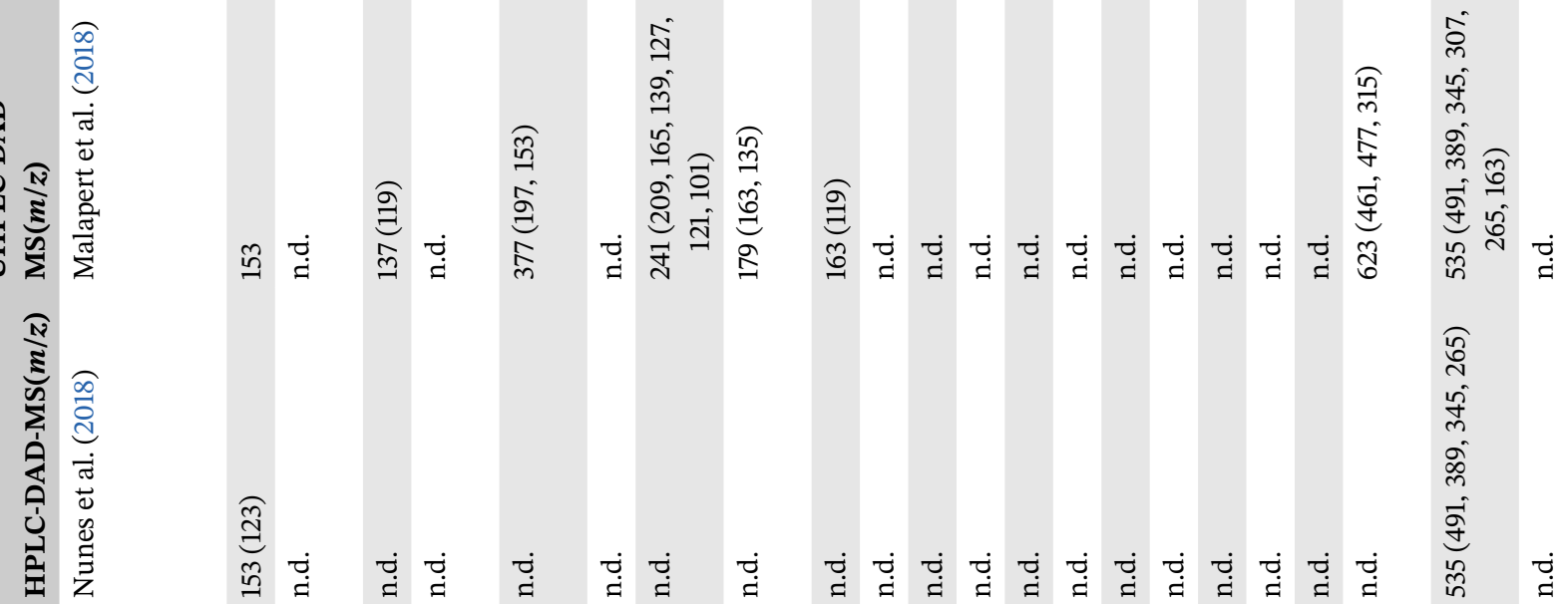

त્ત્ત

¿ேं

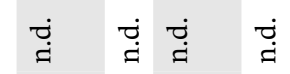

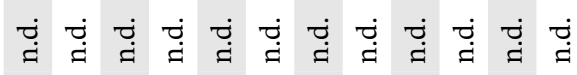

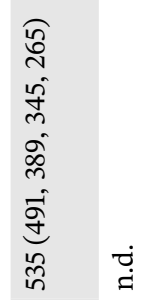

$\sum_{\sum^{n}}^{\infty}$

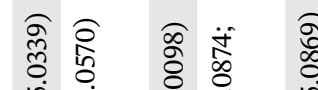

สิ

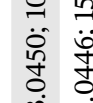

永

它

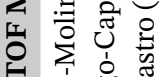

స్తి

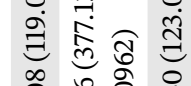

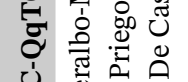

要

要

吕

辛

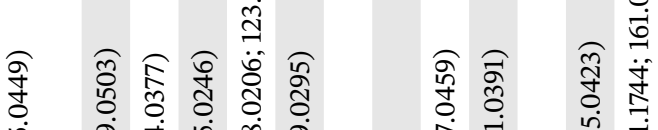

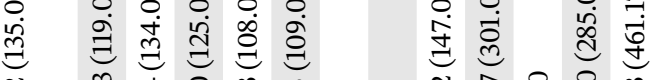

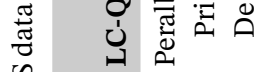

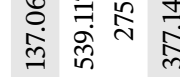

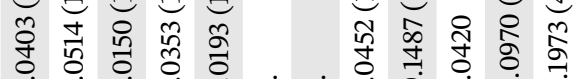

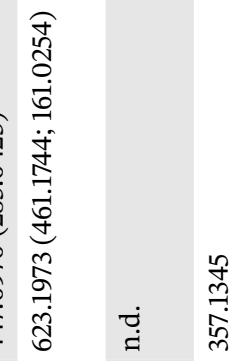

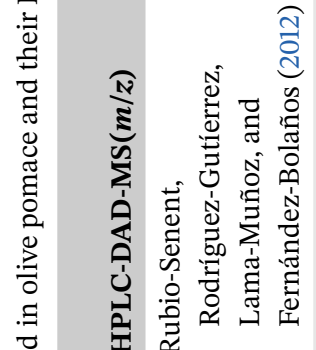

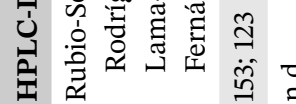

官 $\ddot{\bar{\sigma}}$

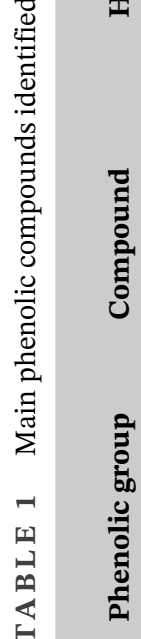

ติ

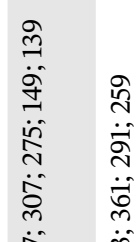

ฌे

के

ர्ف

.

ठี

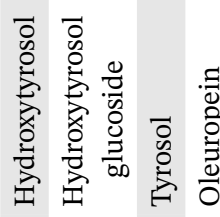

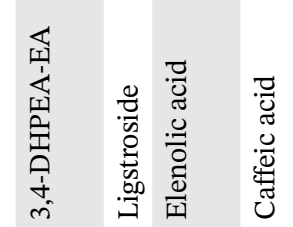

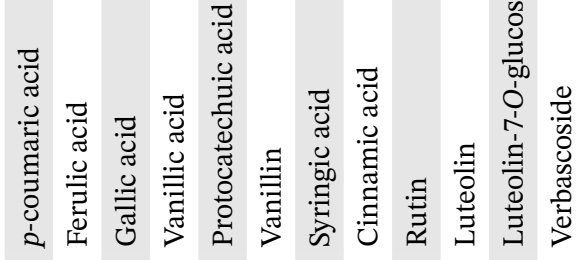

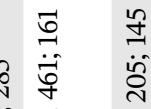

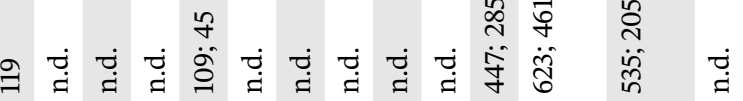
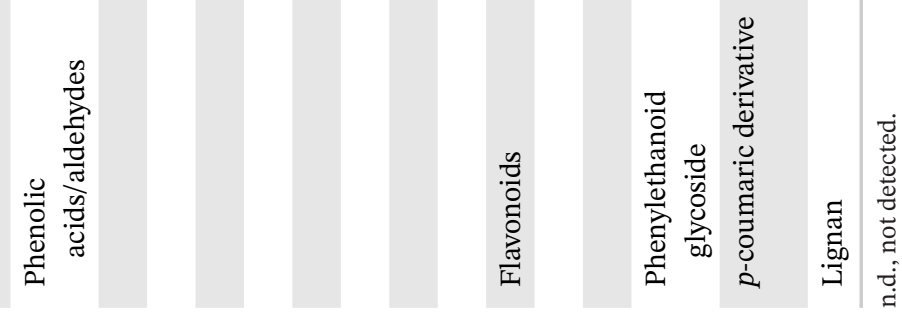
TA B L E 2 Health effects reported for the main phenolic compounds present in olive pomace

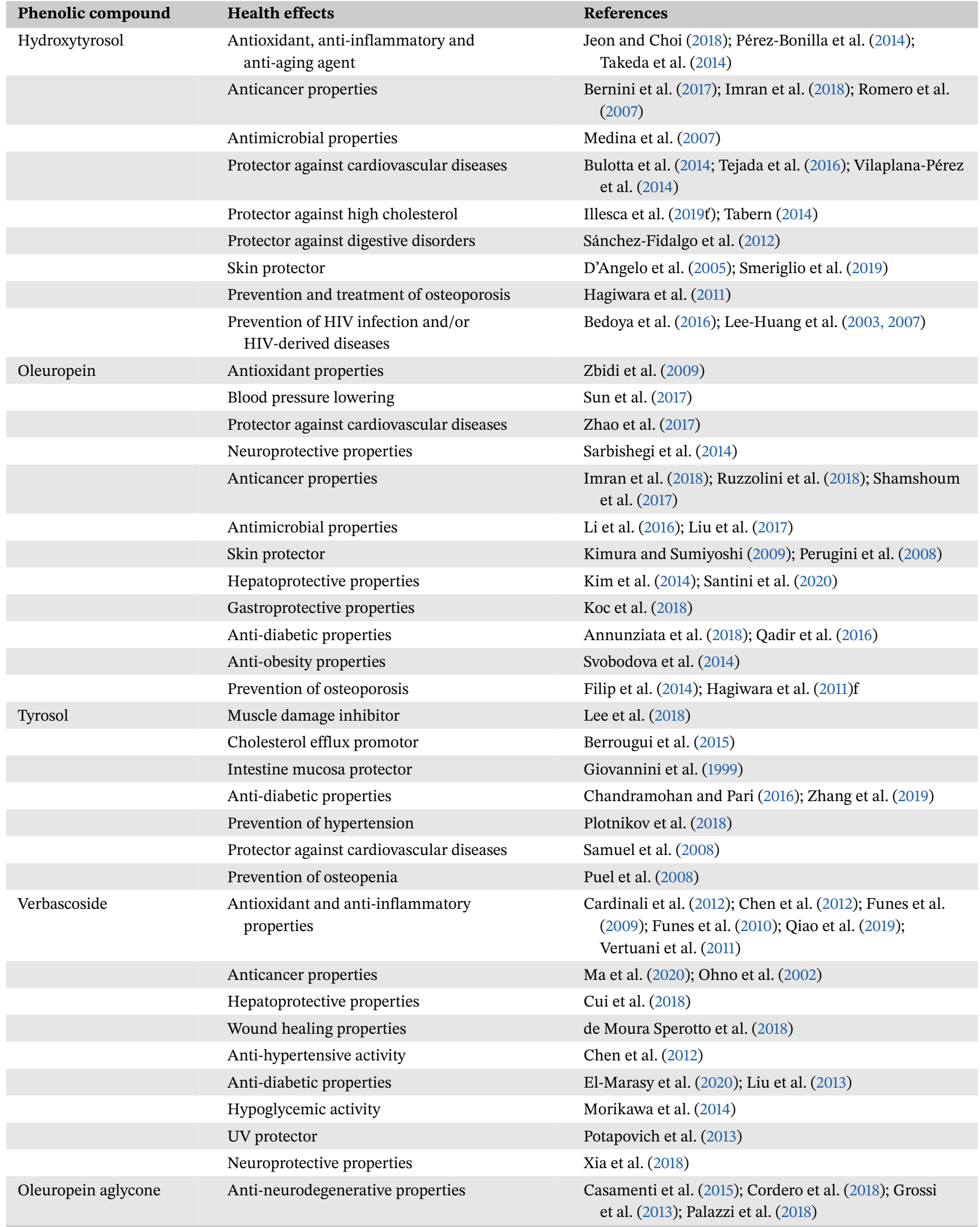


TA B LE 2 (Continued)

\begin{tabular}{lll} 
Phenolic compound & Health effects & References \\
& Anticancer properties & Menendez et al. (2007) \\
& Lipid-lowering properties & Leenen et al. (2002) \\
& Anti-hyperglycemic properties & Rigacci et al. (2010)r \\
& Anti-obesity properties & Oi-Kano et al. (2017) \\
& Antimicrobial properties & Bisignano et al. (2014) \\
\hline
\end{tabular}

HIV, human immunodeficiency virus; UV, ultraviolet.

fortified food with the presented bioactive compounds.

As the most abundant bioactive compounds in olive pomace, hydroxytyrosol, oleuropein, and tyrosol will be discussed first in this section, followed by verbascoside and oleuropein aglycone, which are present in lower amounts in this residue but have beneficial properties and potential applications that should be explored.

\section{1 | Hydroxytyrosol}

Hydroxytyrosol (Figure 2), also known as 3,4-dihydroxyphenylethanol (DOPET), 3,4-dihydroxyphenolethanol (3,4-DHPEA), or 4-(2-hydroxyethyl)-1,2-benzenediol by the International Union of Pure and Applied Chemistry (IUPAC), is one of the most powerful naturally derived antioxidants with higher antioxidant potential than butylated hydroxytoluene (BHT), trolox and vitamins $\mathrm{C}$ and $\mathrm{E}$
(Pérez-Bonilla et al., 2014; Zbidi et al., 2009). Hydroxytyrosol is a main product of the hydrolysis of oleuropein (Liu et al., 2018) which occurs during the ripening of the olives, storage of the oil, and preparation of table olives, and it is responsible for the complexity and variety of the oil and olive flavors. Due to its amphipathic character, hydroxytyrosol can be found not only in olive and in olive leaf, but also in olive oil byproducts in a free form, as acetate form or as part of more complex compounds like oleacein, verbascoside, and oleuropein.

There are different patented methods to obtain purified hydroxytyrosol from products and byproducts of olive oil industry to be used in food, cosmetic, and pharmaceutical industries (Table 3). Thus, nanofiltration and reverse osmosis were patented as clean technologies to purify hydroxytyrosol (de Magalhães Nunes da Ponte et al., 2014), whereas a process using resins was patented by FernandezBolaños Gusman et al. (2005).<smiles>OCCc1ccc(O)c(O)c1</smiles>

Hydroxytyrosol<smiles>OCCc1ccc(O)cc1</smiles>

Tyrosol<smiles>C/C=C1\[C@H](O[C@@H]2O[C@H](CO)[C@@H](O)[C@H](O)[C@H]2O)OC=C(C(=O)OC)[C@H]1CC(=O)OCCc1ccc(O)c(O)c1</smiles>

Verbascoside<smiles>C[C@@H]1O[C@H](O[C@@H]2[C@H](O)[C@@H](OCCc3ccc(O)c(O)c3)O[C@@H](CO)[C@@H]2OC(=O)/C=C/c2ccc(O)c(O)c2)[C@H](O)[C@@H](O)[C@H]1O</smiles><smiles>C/C=C1\C(O)OC=C(C(C)=O)C1CC(=O)OCCc1ccc(O)c(O)c1</smiles>

Oleuropein aglycon

F I G U R E 2 Chemical structures of some of the main phenolic compounds present in olive pomace, discussed in this review 
TA B L E 3 Patents on the application of phenolic compounds present in olive pomace

\begin{tabular}{|c|c|c|c|c|}
\hline \# Patent & Subject & Industry application & $\begin{array}{l}\text { Year of } \\
\text { publication }\end{array}$ & References \\
\hline WO 2004/069218 A1 & $\begin{array}{l}\text { Cosmetic formulation containing } \\
\text { verbascoside to use as a stimulant agent } \\
\text { for the production of thermal shock } \\
\text { proteins and as an inhibitor of } \\
\text { collagenase and elastase and stimulant of } \\
\text { hydroxylases. }\end{array}$ & Cosmetic industry & 2004 & $\begin{array}{l}\text { Robin and Rolland } \\
\text { (2004) }\end{array}$ \\
\hline WO 2007/012057 A2 & $\begin{array}{l}\text { Production of a hydroxytyrosol-rich } \\
\text { formulation to treat skin inflammations, } \\
\text { such as psoriasis, eczema, allergic } \\
\text { dermatitis, phytohypersensitivity, } \\
\text { dermatosis, and lichen urticatus. }\end{array}$ & Pharmaceutical industry & 2007 & Numano et al. (2007) \\
\hline WO 2007/051829 A1 & $\begin{array}{l}\text { Production of a medication using } \\
\text { oleuropein for preventing and/or } \\
\text { treating peripheral vascular disease, } \\
\text { particularly venous insufficiency. }\end{array}$ & Pharmaceutical industry & 2007 & Martín et al. (2007) \\
\hline WO 2008/128629 A1 & $\begin{array}{l}\text { Production of a nutraceutical composition } \\
\text { with hydroxytyrosol for regeneration and } \\
\text { repair of cartilage injuries in joints. }\end{array}$ & Nutraceutical industry & 2008 & Raederstorff et al. (2008) \\
\hline WO 2009/013596 A2 & $\begin{array}{l}\text { Process of production of food } \\
\text { hydroxytyrosol-enriched products } \\
\text { (fortified edible oils, fortified edible } \\
\text { oil-containing products, and dietary } \\
\text { supplements in the form of soft gel } \\
\text { capsules containing fortified edible oils) } \\
\text { to prevent or treat cardiovascular } \\
\text { diseases, plaque build-up in the arteries, } \\
\text { arterial hypertension, and metabolic } \\
\text { syndrome. }\end{array}$ & Nutraceutical industry & 2009 & Más et al. (2009) \\
\hline US 2010/0297330 A1 & $\begin{array}{l}\text { Production of yogurts with hydroxytyrosol } \\
\text { to increase the antioxidant activity, } \\
\text { preserving their organoleptic } \\
\text { characteristics and stability for at least } \\
\text { three months, having the role of } \\
\text { preventing diseases. }\end{array}$ & Food industry & 2010 & Villanova et al. (2010) \\
\hline WO 2010/070183 A1 & $\begin{array}{l}\text { Preparation of therapeutic compositions } \\
\text { with oleuropein as active ingredient to } \\
\text { induce angiogenesis and vasculogenesis. }\end{array}$ & Pharmaceutical industry & 2010 & $\begin{array}{l}\text { Quesada-Gómez et al. } \\
\text { (2010) }\end{array}$ \\
\hline WO 2011/141611 A1 & $\begin{array}{l}\text { Pharmaceutical compositions containing } \\
\text { oleuropein as the only active ingredient } \\
\text { to heal wounds and ulcers in elderly } \\
\text { people and/or diabetics. }\end{array}$ & Pharmaceutical industry & 2011 & $\begin{array}{l}\text { Quesada-Gómez et al. } \\
\text { (2011) }\end{array}$ \\
\hline US 2011/0144040 A1 & $\begin{array}{l}\text { Compositions containing verbascoside and } \\
\text { verbascoside-rich extracts to increase } \\
\text { strength, muscle power, endurance, } \\
\text { muscle protein content, and to reduce } \\
\text { fatigue. }\end{array}$ & Nutraceutical industry & 2011 & $\begin{array}{l}\text { Panyam and } \\
\text { Chavanpatil (2011) }\end{array}$ \\
\hline WO 2011/153647 A1 & $\begin{array}{l}\text { Pharmaceutical composition containing } \\
\text { hydroxytyrosol and xanthohumol to treat } \\
\text { asthma and rhinitis. }\end{array}$ & Pharmaceutical industry & 2011 & $\begin{array}{l}\text { Ehrenberger and } \\
\text { Bieberschulte (2011) }\end{array}$ \\
\hline
\end{tabular}


TABLE 3 (Continued)

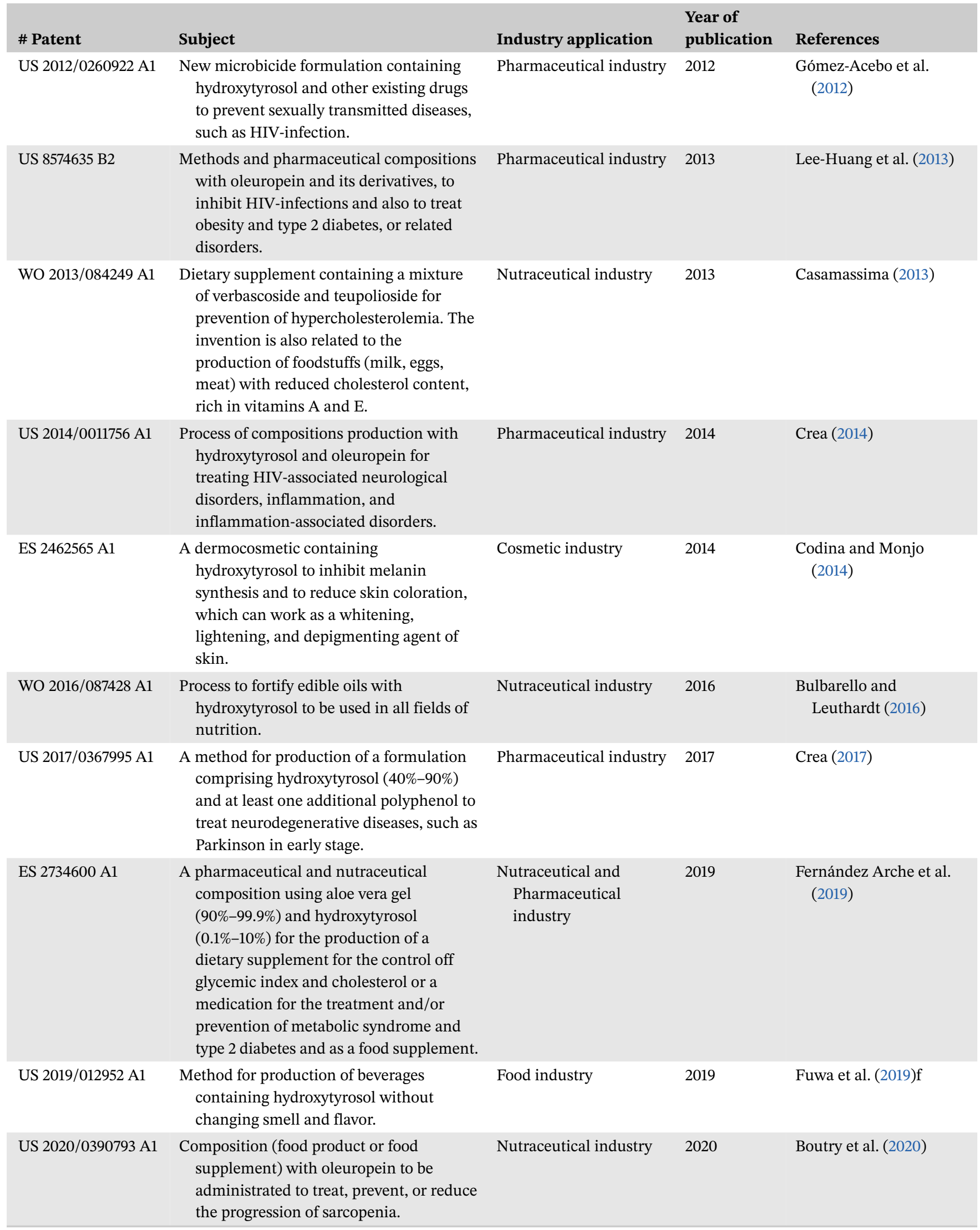

HIV, human immunodeficiency virus. 
TA B L E 4 Fortified food with phenolic compounds present in olive pomace

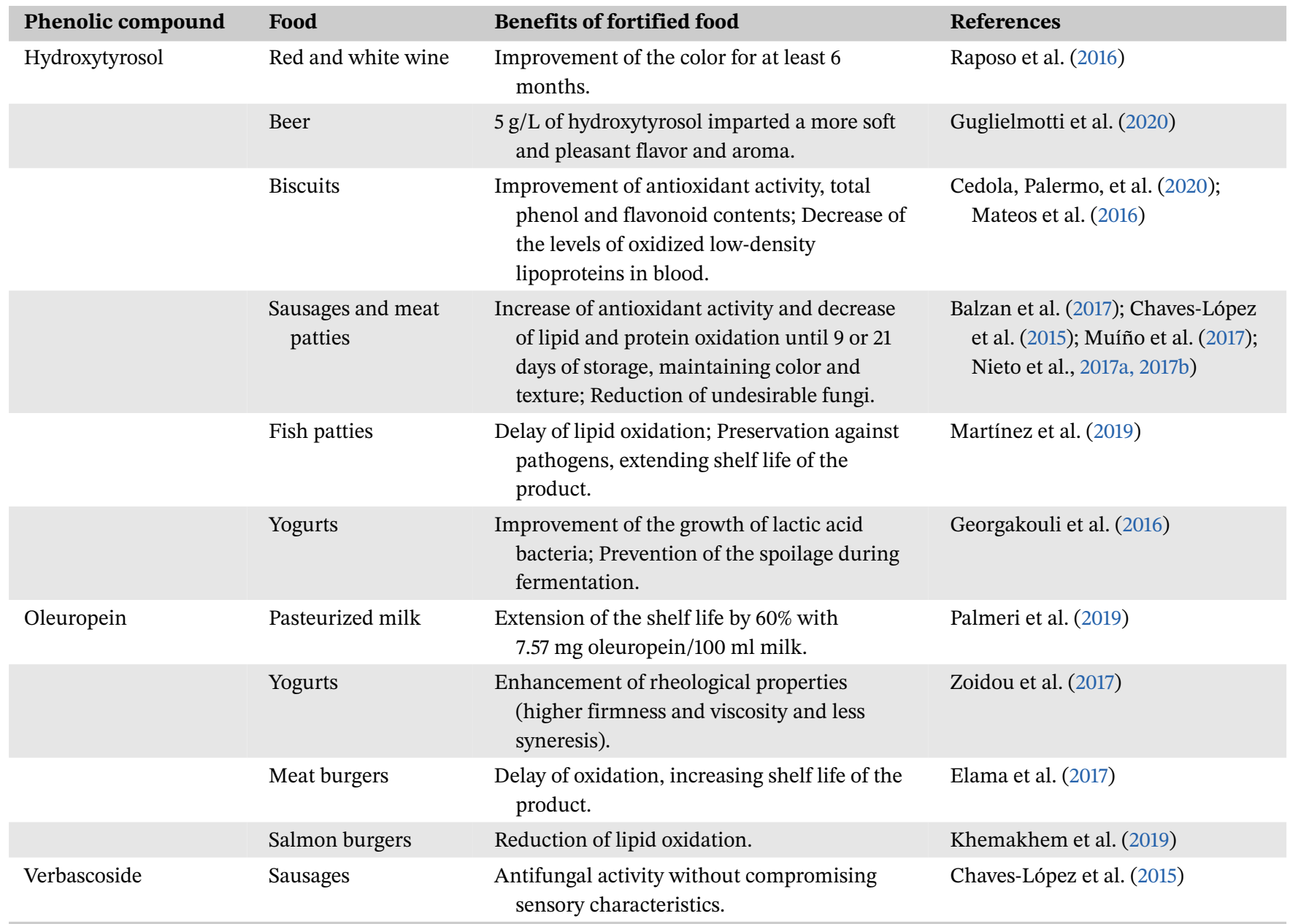

This compound has been described as an antioxidant with many biological activities (Table 2) (Bertelli et al., 2020; Marković et al., 2019; Vilaplana-Pérez et al., 2014). There are many studies proving its antioxidant, anticancer, anti-inflammatory, and antimicrobial activities (Bernini et al., 2017; Bernini et al., 2015; Imran et al., 2018; Jeon \& Choi, 2018; Medina et al., 2007; Pérez-Bonilla et al., 2014; Romero et al., 2007; Takeda et al., 2014). In addition, it was reported to act as a protector against high cholesterol blood levels (Tabern et al., 2014), metabolic diseases (Bulotta et al., 2014; Fki et al., 2020), genotoxicity, cytotoxicity and proapoptotic effects (Anter et al., 2014; Bernini et al., 2013), oxidative stress (Loru et al., 2009; Merra et al., 2014), and digestive disorders (Sánchez-Fidalgo et al., 2012). Other works have focused on the use of hydroxytyrosol in cardiovascular diseases (Bulotta et al., 2014; Tejada et al., 2016; Vilaplana-Pérez et al., 2014).

D’Angelo et al. (2005) and Smeriglio et al. (2019) demonstrated the dermatological properties of hydroxytyrosol to prevent protein damage induced by long-wavelength ultraviolet radiation in melanoma cells or to counteract atopic dermatitis, respectively. More specifically, Smeriglio et al. (2019) investigated the safety and efficacy of the Fenolia $₫$ Eudermal Cream 15 containing hydroxytyrosol in its formulation, which was demonstrated to be effective in improving the epidermal barrier effect, preventing inflammation, and repairing the skin. Actually, hydroxytyrosol is already used as an ingredient in different cosmetics, including anti-aging and lightening/whitening products. There are a few patents to produce cosmetics with hydroxytyrosol. Codina and Monjo (2014) patented a method to produce a dermocosmetic containing hydroxytyrosol to inhibit melanin synthesis, reduce skin coloration and work as a whitening, lightening, and depigmenting agent of skin. Another hydroxytyrosol-rich formulation was developed to treat skin inflammations, such as psoriasis, eczema, allergic dermatitis, photohypersensitivity dermatosis, or lichen urticatus (Numano et al., 2007).

Hydroxytyrosol has been proposed to promote fat and cholesterol metabolism, effectively protect the liver function, and cure and/or prevent the occurrence of obesity. In a study with high-fat diet fed mice, hydroxytyrosol was used as a nutritional supplement to amend dysfunctional white adipose tissue (Illesca et al., 2019). The 
supplementation caused an improvement on adipocyte hypertrophy and a decrease in oxidative damage, showing it as a promising alternative to prevent obesity and its associated metabolic disturbances. A pharmaceutical or nutraceutical composition was developed and patented by Arche et al. (2019) based on an aloe vera (90-99.9\%) and hydroxytyrosol $(0.1 \%-10 \%)$ gel to be used as a dietary supplement for the control of glycemic index and high cholesterol levels or a medication for the treatment and/or prevention of metabolic syndrome and type 2 diabetes.

An interesting study by Hagiwara et al. (2011) proposed the use of hydroxytyrosol on osteoporosis' prevention and treatment, since this compound stimulated the deposition of calcium in a dose-dependent manner. Furthermore, nutraceutical and pharmaceutical compositions with hydroxytyrosol were patented for regeneration and repair of cartilage injuries in joints (Raederstorff et al., 2008).

A formulation comprising hydroxytyrosol (40\%-90\%) and at least one additional olive polyphenol was developed for the treatment of neurodegenerative diseases such as Parkinson in the early stages of the disease (Crea, 2017). The inventors described the administration of daily doses of capsules (72 mg olive polyphenols, including $30 \mathrm{mg}$ hydroxytyrosol) to subjects for some weeks, noticing considerable improvements in their movements and reduction of the tremor after the first weeks.

The use of hydroxytyrosol to prevent human immunodeficiency virus (HIV) infection and even to palliate HIV-derived diseases has also received special attention (Bedoya et al., 2016; Lee-Huang et al., 2007; Lee-Huang et al., 2003). Bedoya et al. (2016) observed that 5hydroxytyrosol inhibited HIV-1 infections of recombinant or wild-type viruses in human lymphoblastic cells (MT-2 cell lines) and human peripheral blood mononuclear cells (PMBCs cell lines). The combination of this compound with other drugs already used as a preventive treatment against HIV-1 infections was also tested. Additive effects were found with lamivudine and emtricitabine, whereas the combination with tenofovir seemed to be synergistic. These findings, which suggested that 5-hydroxytyrosol could be an effective and low-cost new microbicide to prevent the HIV infection with particular interest in countries with high incidence of transmission were patented by Gómez-Acebo et al. (2012). Another method for producing pharmaceutical compositions with phenolic compounds extracted from olive byproducts, including hydroxytyrosol, for treating HIV-associated neurological disorders, inflammation, and inflammation-associated conditions was patented (Crea, 2014). This composition was produced to be preferably used as a tablet formulation for oral administration.
A formulation containing hydroxytyrosol and xanthohumol as active substances in the form of an intranasal spray was also patented to treat asthma and rhinitis as well as to treat colds (Ehrenberger \& Bieberschulte, 2011).

The European Food Safety Authority (EFSA) concluded that there was sufficient scientific evidence to claim several health benefits for hydroxytyrosol and related olive oil polyphenols (EFSA Panel on Dietetic Products, Nutrition \& Allergies, 2011), and that no concerns exist about its safety to be used in novel food preparations under proposed uses and levels (EFSA Panel on Dietetic Products, Nutrition \& Allergies, 2017). A summary on the uses of hydroxytyrosol in fortified foods is collected in Table 4. A comprehensive review on the applications of hydroxytyrosol as a functional food ingredient, either in the form of pure compound or hydroxytyrosol-rich extracts, was recently published by Silva et al. (2020). In that review, the authors described the use of this compound in edible oils, beverages, bakery products and meat, fishery, and dairy products. Several food products with higher antioxidant activity (fortified edible oils, fortified edible oil-containing products, and dietary supplements in the form of soft gel capsules containing fortified edible oils) were patented by Mas et al. (2009) for preventing or treating cardiovascular diseases, plaque build-up in the arteries, arterial hypertension, and metabolic syndrome, based on their hydroxytyrosol-rich composition. Bulbarello and Leuthardt (2016) patented capsules for oral consumption of an edible oil fortified with hydroxytyrosol (more than $250 \mathrm{mg}$ hydroxytyrosol/ $\mathrm{kg}$ fortified oil) to be used in humans and animals in all the fields of nutrition. Besides its health benefits, the fortification with hydroxytyrosol can delay the oxidation of edible oils.

Moderate consumption of red wine has been suggested to protect against cardiovascular diseases mainly due to its high content in polyphenols (Santos-Buelga \& GonzálezManzano, 2011). When hydroxytyrosol is added to red (Raposo et al., 2016a) and white (Raposo et al., 2016b) wines to replace the use of sulfur dioxide, an intensification of color was noticed. The improvement on color was maintained even after 6 months of storage for white wines, whereas red wines were oxidized. Based on these results, the authors suggested that the combination of sulfur dioxide with hydroxytyrosol could be a suitable condition to reduce the sulfur dioxide content without compromising the wine oxidation. Recently, Guglielmotti et al. (2020) incorporated hydroxytyrosol in beer using olive leaves as an ingredient in the form of dry crumbled leaves, infusion and atomized extract, so as to explore their contribution to bitterness and antioxidant activity of beer. The ingredients were added during boiling phase of brewing, in order to promote the hydrolysis of oleuropein of the leaves to hydroxytyrosol. The results demonstrated that the 
addition of $10 \mathrm{~g} / \mathrm{L}$ of olive leaves imparted a sour/astringent taste and herbal aroma to the beers, whereas $5 \mathrm{~g} / \mathrm{L}$ of olive left a softer and pleasant flavor and aroma in comparison to the control. Fuwa et al. (2019) studied the possibility of preparing a beverage containing hydroxytyrosol ( 0.5 to $50 \mathrm{mg} / 100 \mathrm{ml}$ ) to improve blood flow without changing smell and flavor. The authors formulated beverages comprising ethanol and/or propylene glycol ( $0.05 \%$ to $0.5 \%$ $\mathrm{w} / \mathrm{v})$, caffeine (10-210 mg/100 ml), and glucose and maltose. The beverages with the most favorable taste were found to be the ones with higher concentrations of caffeine ( $>110 \mathrm{mg}$ of caffeine/100 ml) and $0.8-1.5 \mathrm{mg}$ of hydroxytyrosol/100 $\mathrm{ml}$. The beverages with the most favorable sense of quick sweetness were those containing $0.8-1.5 \mathrm{mg}$ of hydroxytyrosol/100 $\mathrm{ml}$ and a ratio of glucose/maltose of 0.03-0.14

Bakery products are also interesting products to incorporate hydroxytyrosol since they are consumed worldwide by people of different ages. Mateos et al. (2016) observed that the intake by volunteers of hydroxytyrosolfortified biscuits (30 g biscuits providing $5.25 \mathrm{mg}$ of hydroxytyrosol, after an overnight fast) could significantly decrease the levels of oxidized low-density lipoproteins (LDL) in blood, also finding that hydroxytyrosol was highly bioavailable, extensively metabolized, and rapidly eliminated. In another study by Cedola et al. (2020), the white wine used to produce the Italian biscuit "taralli" was replaced by an olive leaves extract containing hydroxytyrosol. An improvement on antioxidant activity (1.5-fold), total phenols ( $\geq 1.4$-fold), and flavonoid content (4-fold) were observed, which could be responsible for the darker color of the fortified biscuits compared to the control ones.

Hydroxytyrosol has been also used in meat to improve the oxidative stability and sensory properties of lamb meat patties (Muíño et al., 2017), the nutritional profile of lowfat chicken Frankfurters (Nieto et al., 2017a) or to reduce the growth of undesirable fungi on dry fermented sausages (Chaves-López et al., 2015). Muíño et al. (2017) evaluated lamb meat patties enriched with omega 3 (fish oil) and hydroxytyrosol at different concentrations $(100,200$, and $400 \mathrm{ppm}$ ), demonstrating that the presence of hydroxytyrosol increased the antioxidant activity of patties and decreased the lipid and protein oxidation at days 3,6, and 9 of storage compared with control samples, while maintaining the color and texture. Hydroxytyrosol (50 ppm), in combination with olive oil and walnuts, was used to produce chicken sausages without loss of sensory attributes during storage at $4^{\circ} \mathrm{C}$ for 21 days. Furthermore, it was enough to maintain the color and reduce lipid and protein oxidation until 21 days (Nieto et al., 2017b; Nieto et al., 2017a). Fermented sausages added with hydroxytyrosol (100.23 ppm) showed lower lipid oxidation and volatile compounds and higher redness, as well as improved anti- fungal activity both in vitro and in situ (Chaves-López et al., 2015). Also, Balzan et al. (2017) prevented the lipid oxidation of pork sausages using a purified extract from the olive vegetation water containing a high amount of hydroxytyrosol.

In fishery products, hydroxytyrosol was efficient to inhibit the formation of lipid oxidation products in bulk cod liver oil (100 ppm of hydroxytyrosol), cod liver oilin-water emulsions (100 ppm of hydroxytyrosol), and frozen minced horse mackerel (Trachurus trachurus) muscle (50 ppm of hydroxytyrosol) (Pazos et al., 2008); furthermore, the level of $\alpha$-tocopherol and the $\omega$-3 long-chain PUFAs was preserved. Hydroxytyrosol extracts were also able to delay the lipid oxidation and preserve fish patties against Escherichia coli, Listeria monocytogenes, and Staphylococcus aureus contributing to extend their shelf life (Martínez et al., 2019).

The production of yoghurts that include hydroxytyrosol (in a percentage between $0.1 \%$ and $0.01 \%$ ) as an additional healthy component was patented by Villanova et al. (2010). The enriched yogurts preserved their organoleptic characteristics, improved their antioxidant activity, and maintained their stability for at least 3 months. In the same way, Georgakouli et al. (2016) verified that the addition of a commercial hydroxytyrosol-rich product obtained from olive fruits (Medoliva $\subseteq$ ) in yogurts (50 mg of polyphenols) improved the growth of lactic acid bacteria and contributed to preventing spoilage during fermentation, as well as to reduce LDL cholesterol, body weight, and blood pressure.

\section{2 | Oleuropein}

Oleuropein belongs to a very specific group of coumarinlike compounds, called secoiridoids and consists of hydroxytyrosol, elenolic acid, and a glucose molecule (Figure 2). It is one of the main polyphenols present in olive wastes, contributing to the bitter taste of olive oil and fruit.

Oleuropein possesses numerous pharmacological benefits (Table 2) mostly related with its strong antioxidant and anti-inflammatory activities (Hassen et al., 2015; Marković et al., 2019; Nediani et al., 2019). The antioxidant activity of oleuropein is related to the presence of hydroxyl groups in its chemical structure that can donate hydrogen to prevent oxidation (Hassen et al., 2015). In fact, oleuropein and oleuropein-rich extracts were reported to have higher antioxidant activity than the synthetic antioxidant BHT (Zbidi et al., 2009). Another interesting property of oleuropein is its blood pressure-lowering effect. Sun et al. (2017) found that oleuropein can protect the paraventricular nucleus (PVN) of hypothalamus from oxidative stress, being a promising strategy both for preventing and treating hypertension. Furthermore, oleuropein has been shown to 
have cardioprotective (Zhao et al., 2017), neuroprotective (Sarbishegi et al., 2014), anticancer (Imran et al., 2018; Ruzzolini et al., 2018; Shamshoum et al., 2017), and antimicrobial (Li et al., 2016; Y. Liu et al., 2017) activities. Also, it was proven to possess skin protectant (Kimura \& Sumiyoshi, 2009; Perugini et al., 2008), hepatoprotective, gastroprotective, anti-diabetic and anti-obesity activities, and lipid regulating effects (Annunziata et al., 2018; Drira et al., 2011; Kim et al., 2014; Koc et al., 2018; Qadir et al., 2016; Santini et al., 2020; Svobodova et al., 2014). Based on the mentioned properties, oleuropein may be used for a variety of human disorders.

Martín et al. (2007) developed a patent on the use of oleuropein for the manufacture of a medication for preventing and/or treating a condition associated with peripheral vascular disease. A pharmaceutical composition with oleuropein (concentration between $10^{-7}$ and $10^{-4} \mathrm{M}$ ) as active ingredient was also patented to induce angiogenesis and vasculogenesis, that can be administered by oral, rectal, parenteral, intraperitoneal, intradermal, transdermal, intratracheal, intramuscular, intravenous, or inhalation (Quesada-Gómez et al., 2010). The same authors (Quesada-Gómez et al., 2011) patented a preparation containing oleuropein as the only active ingredient to be used for healing wounds and ulcers in aged and/or diabetics individuals in the form of gel, cream, or aqueous solution form.

The above mentioned medication, hydroxytyrosol based, for treating an AIDS-associated neurological disorders can also be prepared using a mixture of hydroxytyrosol and oleuropein (Crea, 2014). Lee-Huang et al. (2013) also patented a formulation able to inhibit not only the infectivity of HIV but also to treat and prevent obesity and related conditions, such as type 2 diabetes. Actually, interesting evidences have been found on the effects of oleuropein on the control of type 2 diabetes (Annunziata et al., 2018).

Oleuropein also has application in the treatment of osteoporosis. The BONOLIVE $\AA$ supplement, consisting of a polyphenols mixture from olive leaf containing more than $40 \%$ of oleuropein, has been clinically proven to induce significant effects on bone health, stimulating bone building cells (osteoblasts), and improving blood lipid profiles in individuals after 12 months of treatment (Filip et al., 2014). Hagiwara et al. (2011) also reported that, as hydroxytyrosol, oleuropein may have critical effects on the formation and maintenance of bone, and that both could be used as effective medications for the treatment of osteoporosis symptoms.

Recently, Boutry et al. (2020) described a formulation to be used either as a food product or a food supplement, based on oleuropein to treat or prevent sarcopenia, indicated for elderly and/or frail individuals.
Oleuropein has been added as an active ingredient in milk and yogurt preparations for the production of novel foods with improved characteristics. Palmeri et al. (2019) observed that the addition of 5\% olive leaf extract (corresponding to $7.57 \mathrm{mg}$ of oleuropein/100 $\mathrm{ml}$ of milk) to pasteurized milk was able to extend its shelf life by $60 \%$, thus leading to significant benefits in terms of costs linked to transport and to product returns to the dairy industry. The incorporation of oleuropein to fortify yogurts represents a major challenge for their taste and texture. Nevertheless, Zoidou et al. (2017) proved that the addition of olive leaf extract containing high amounts of oleuropein to yogurts improved their rheological properties, providing higher firmness and viscosity, and less syneresis.

Oleuropein can also be used for delaying the oxidation of meat. Elama et al. (2017) explored the possibility of using oleuropein as a natural antioxidant in frozen hamburgers to replace synthetic food antioxidants such as sodium erythorbate. Similar results were obtained for both oleuropein and sodium erythorbate, finding that a concentration of $0.5 \%$ was able to extend shelf life of hamburgers and hinder oxidation. The potential of oleuropein to preserve salmon burgers by reducing lipid oxidation during the storage at low temperatures was also demonstrated (Khemakhem et al., 2019).

\section{3 | Tyrosol}

Tyrosol (Figure 2), also named as 2-(4-hydroxyphenyl)ethanol, $p$-hydroxyphenethyl alcohol, or 4-(2-hydroxyethyl)-phenol by the IUPAC, is a phenylethanoid compound naturally present in olive fruit, olive oil, and olive wastes both in their free form or as part of more complex molecules, mostly as esters of elenolic acid.

Several studies have demonstrated the potential of tyrosol as antimicrobial, anti-carcinogenic, antiinflammatory, and antioxidant agent (Table 2). Tyrosol has been proposed to fight hypertension, atherosclerosis, coronary heart disease, chronic heart failure, insulin resistance, and obesity by modulating cluster of differentiation 14 (CD14) upregulation and inhibiting inflammation (Chang et al.,). In a study developed by Lee et al. (2018), tyrosol showed to be effective in inhibiting muscle damage from oxidative stress triggered by strenuous exercise. Tyrosol could also promote cholesterol efflux by enhancing the antiatherogenic properties of high-density lipoproteins (HDL) (Berrougui et al., 2015) and protect the intestine mucosa by preventing the oxidative damage induced by LDL, as shown in human colon adenocarcinoma cell line, Caco-2 (Giovannini et al., 1999).

Tyrosol may also play a role in the treatment of diabetes mellitus, exerting anti-inflammatory effects on 
the liver and pancreas via its antioxidant activity, as observed in streptozotocin-induced diabetic rats (Chandramohan \& Pari, 2016). Furthermore, the intramuscular administration of tyrosol to diabetic hind limb ischemia mice significantly enhanced the formation of blood vessels which improved the recovery of blood perfusion (Zhang et al., 2019). Those authors also reported a cytoprotective function of tyrosol against hyperglycemia-induced oxidative stress in skeletal muscle cells and an increase in their proliferation.

Plotnikov et al. (2018) described that when tyrosol was administered to young spontaneously hypertensive rats (SHRs), the development of hyperviscosity syndrome was limited, the oxygen transport capacity was improved, and the microvascular rarefaction in the cerebral cortex was eliminated. The blood viscosity increased by $16 \%-26 \%$ in rats treated with tyrosol and the results were similar to those obtained with pentoxyphylline, a drug used for the treatment of peripheral circulation disorders (Plotnikov et al., 2007). Samuel et al. (2008) verified that a tyrosol treatment ( $5 \mathrm{mg} / \mathrm{kg} /$ day for 30 days) was capable of inducing myocardial protection against ischemia-induced stress in rats, which turns important in order to develop a new drug to combat cardiovascular diseases. Moreover, Puel et al. (2008) reported that the daily consumption of tyrosol during 84 days by ovariectomized rats increased bone formation, which was associated with its antioxidant properties, thus preventing osteopenia.

In spite of its interesting properties, the hydrophilic chemical nature of tyrosol could limit its use in foods, pharmaceutical formulations, and/or cosmetics. Paulo and Santos (2020a) developed a strategy to incorporate tyrosol in alternative polymer carriers as poly(D,L-lactideco-glycolide), ethylcellulose, and polycaprolactone by water-in-oil-in-water double emulsion solvent evaporation technique. The obtained results revealed that these microparticles were thermogravimetrically stable in the temperature range of 30 to $261^{\circ} \mathrm{C}$. Actually, the bioaccessibility of tyrosol improved by 1.9-fold when the compound was encapsulated (Paulo \& Santos, 2020b). Being an antioxidant compound, the microencapsulation may also protect tyrosol from auto-oxidation processes. Other recent study reported the impact of two different carriers for the encapsulation of tyrosol: the oligosaccharide $\beta$-cyclodextrin and the polysaccharide chitosan (Pintillo et al., 2021). The results demonstrated that the coating promoted a sustained release of tyrosol and slowed down the initial burst effect observed from the inclusion complex. Also, this compound was shown to be a ctDNA groove binder. These outcomes bring new insights concerning the encapsulation of antioxidants for further incorporation in food, pharmaceutical, cosmetic, and/or nutraceutical matrices.

\section{4 | Verbascoside}

Verbascoside (Figure 2), also known as acteoside, belongs to the extensive family of phenylpropanoids and is a conjugated glucoside of hydroxytyrosol and caffeic acid. This compound has been demonstrated to have antioxidant protective effects on phospholipid membranes and modulation of plasma antioxidant activity in vivo (Chen et al., 2012; Funes et al., 2009; Funes et al., 2010). Cardinali et al. (2012) reported that verbascoside has a high antioxidant capacity, acting as an effective scavenger of biologically active free radicals and an inhibitor of lipid peroxidation, so that it can be used for treating oxidative stress-related diseases, which may be interesting for application in cosmetics, nutraceuticals, or functional foods. Furthermore, antitumor, antimicrobial, antiinflammatory, anti-thrombotic, and wound healing properties have also been described (Cui et al., 2018; de Moura Sperotto et al., 2018; Ma et al., 2020; Ohno et al., 2002; Qiao et al., 2019; Vertuani et al., 2011).

Chen et al. (2012) reported that verbascoside $(10 \mathrm{mg} / \mathrm{kg}$ body weight) has anti-hypertensive activity, lowering both systolic and diastolic blood pressures in hypertensive rats. Its anti-inflammatory potential was also reported by Qiao et al. (2019) on rats with osteoarthritis, a chronic arthritis, through the inactivation of JAK/STAT signaling pathway. Vertuani et al. (2011) demonstrated the stability of verbascoside in suppositories which is an interesting pharmaceutical form to apply in treatment of inflammation of the intestinal mucosa. This compound also presents antitumor activity possibly by increasing p53 levels, as well as by inhibiting KLK expression and angiogenesis, making it a potential candidate for the treatment of advanced hepatocellular carcinoma in the clinic (Ma et al., 2020).

Hepatoprotective (Cui et al., 2018) and anti-diabetic effects (El-Marasy et al., 2020; Liu et al., 2013) have also been described and hypoglycemic activity and improved glucose tolerance were found by Morikawa et al. (2014) in starch-loaded mice.

Potapovich et al. (2013) suggested that verbascoside could inhibit inflammatory response and metabolic disorders caused by solar UV irradiation in human keratinocytes. Similarly, wound healing activity was reported, as it was demonstrated to be capable of increasing the migration of keratinocytes and inhibiting inflammation mediators (de Moura Sperotto et al., 2018).

Xia et al. (2018) described the capacity of verbascoside in attenuating oxidative stress and neuronal apoptosis in middle cerebral artery occlusion/reperfusion rats. Its administration seemed to reduce infarct volume and brain edema and improve neurological deficits, thus suggesting that it can be successfully used to treat cerebral ischemiareperfusion injury. A review on the biological effects of 
verbascoside and its potential clinical utility have been published by Alipieva et al. (2014).

Casamassima (2013) patented a dietary supplement containing verbascoside and teupolioside for prevention of hypercholesterolemia and the production of foodstuffs (particularly in meat, milk, and eggs) with reduced cholesterol content.

NuLiv Science (https://nulivscience.com/), which works on the research and development of proprietary ingredients for nutraceuticals industry, produced two products containing verbascoside: Acteolin $^{\mathrm{TM}}$ and Verbasnol $^{\mathrm{TM}}$. Acteolin ${ }^{\mathrm{TM}}$ is an ingredient claimed to provide benefits for cognitive and memory functions, lung, and eye health. Verbasnol ${ }^{\mathrm{TM}}$ helps boost the skin's natural ability and sweeps away the adverse effects of sunlight, oxidative stress, and dryness while maintaining skin hydration and elasticity. Robin and Rolland (2004) patented a formulation containing verbascoside to use in cosmetics as a stimulant agent for the production of thermal shock proteins and as an inhibitor of collagenase and elastase in the skin cells.

In recent years, there has been a growing interest to improve athletic performance and body composition (the ratio of lean to fat mass). Panyam and Chavanpatil (2011) patented preparations containing verbascoside or verbascoside-rich extracts to be administrated in capsule, pill, powder, edible bar, or liquid form in order to increase strength, muscle power, endurance, muscle protein content, and to reduce fatigue. Tu et al. (2005) patented a drug with verbascoside (5\%-40\%) as an active ingredient to prevent senile dementia and inhibit aggregation of blood platelets.

Concerning the use of this compound in food, ChavesLópez et al. (2015) demonstrated that verbascosiderich $(135.20 \mathrm{ppm})$ extracts incorporated to fermented sausages had antifungal activity without inducing significant changes on sensory characteristics, thus being considered a potential alternative to synthetic antifungal compounds.

\section{5 | Oleuropein aglycone}

Oleuropein aglycone (Figure 2), also known as 3,4DHPEA-EA (i.e., 3-4-DHPEA-elenolic acid mono-aldehyde, IUPAC name: methyl (2R,3Z,4S)-4-\{2-[2-(3,4-dihydroxyphenyl)ethoxy]-2-oxoethyl\}-3-ethylidene-2-hydroxy-3,4-dihydro-2H-pyran-5-carboxylate), is a secoiridoid formed from the deglycosylation of oleuropein, which can be produced by enzymatic, acid or acetal hydrolyses (Xu et al., 2018). Several studies referred to it as the main polyphenol present in olive oil (e.g., Cordero et al., 2018; Xu et al., 2018), but it is also abundant in olive wastes. In recent times, this compound has gained attention due to its biological activities, including anti-neurodegenerative diseases, anti-breast cancer, anti-inflammatory, antihyperglycemic, antioxidant, and lipid-lowering properties (Grossi et al., 2013; Menendez et al., 2007; Oi-Kano et al., 2017; Palazzi et al., 2018; Rigacci et al., 2010; Xu et al., 2018).

Oleuropein aglycone has the ability of promoting the autophagy, thus being associated with a reduction of symptoms of Alzheimer's disease and cognitive impairment (Casamenti et al., 2015; Cordero et al., 2018). Grossi et al. (2013) found that the administration of oleuropein aglycone in young/middle-aged TgCRND8 mice for 8 weeks could improve memory and animal behavior by interfering with $\mathrm{A} \beta$ aggregation. Oleuropein aglycone was also seen to slow down amyloid aggregation by stabilizing $\alpha$ synuclein monomers, thus hampering their progression to cytototoxic amyloids, which could be helpful in the prevention of Parkinson's disease. In addition, it may also hinder the binding of $\alpha$-synuclein aggregates to cell membrane components thus preventing cell oxidative damage (Palazzi et al., 2018). Leri and Bucciantini (2016) reported that oleuropein aglycone could inhibit the toxic effects of transthyretin (TTR) amyloid and be important to prevent or treat heart and liver complications. It has also been shown to be capable of preventing or delaying the progression of type 2 diabetes (Rigacci et al., 2010) and obesity (Oi-Kano et al., 2017). Oi-Kano et al. (2017) reported that it reduced the visceral fat content in high-fat dietinduced obese rats by enhancing noradrenaline secretion via $\beta$-adrenergic action following transient receptor potential ankyrin 1 (TRPA1) and vanilloid 1 (TRPV1) activation. Oleuropein aglycone was found to protect LDL in plasma against oxidation (Leenen et al., 2002) as well as to enhance the antioxidant defense system against experimental atherogenesis, which was attributed to its 3,4dihydroxyphenyl ethanol group (Jemai et al., 2008).

Menendez et al. (2007) reported that, among the polyphenols present in olive oil, oleuropein aglycone was the most potent compound in decreasing breast cancer cells viability, by inhibiting the proteolytic processing of human epidermal growth factor receptor2 (HER2).

In a study developed by Bisignano et al. (2014), oleuropein aglycone was found to be effective against American Type Culture Collection (ATCC) and clinical isolates of $S$. aureus (minimum inhibitory concentrations [MIC] values between 125 and $250 \mu \mathrm{g} / \mathrm{ml}$ ) and Staphylococcus epidermidis (MIC values between 7.81 and $62.5 \mu \mathrm{g} / \mathrm{ml}$ ). Although further studies have to be performed in order to understand the mechanisms responsible for these results, this compound could be a potential natural antimicrobial for the treatment of skin infections. 


\section{5 | CONCLUSION}

The compounds present in the wastes generated during the olive oil extraction process may have considerable health benefits and be used, after suitable purification, as food antioxidants or active ingredients in nutraceutical and cosmetic products, because they possess a range of recognized bioactivities, technological, and pharmaceutical properties. Further research on their potential applications should be granted in order to valorize them and maintain environmental sustainability. In addition, it is imperative for the development of green and efficient extraction methods to ensure higher recovery of these compounds and the cooperation between industry and researchers to generate sustainable added value to these byproducts, thus contributing to the circular economy.

\section{ACKNOWLEDG MENTS}

The authors are grateful to the Foundation for Science and Technology (FCT, Portugal) for financial support through national funds FCT/MCTES to C2TN (UIDB/04349/2020), CIMO (UIDB/00690/2020) and Joana Madureira (SFRH/BD/136506/2018). Lillian Barros thank the national funding by FCT, P.I., through the institutional scientific employment program-contract. The authors thank the European Regional Development Fund (ERDF), through the Incentive System to Research and Technological development within the Portugal2020 Competitiveness and Internationalization Operational Program for the mobilizing project "BIOMA" (POCI01-0247-FEDER-046112). The Agroenvironment Unit is supported by Junta de Castilla y León (Escalera de Excelencia CLU-2018-04) co-funded by the P.O. FEDER of Castilla y León 2014-2020.

\section{AUTH OR CONTRIBUTIONS}

Joana Madureira: Data curation; investigation; visualization; writing-original draft, review, and editing. Fernanda M. A. Margaça: Funding acquisition; visualization; writing-review and editing. Celestino Santos-Buelga: Conceptualization; funding acquisition; supervision; visualization; writing-review and editing. Isabel C. F. R. Ferreira: Conceptualization; funding acquisition; project administration; writing_-review and editing. Sandra Cabo Verde: Conceptualization; funding acquisition; supervision; visualization; writing-review and editing. Lillian Barros: Conceptualization; funding acquisition; supervision; writing-review and editing.

\section{CONFLICT OF INTEREST}

The authors declare no conflict of interest.

\section{O R C I D}

Sandra Cabo Verde (1) https://orcid.org/0000-0002-66155289

Lillian Barros (1) https://orcid.org/0000-0002-9050-5189

\section{REFERE N C ES}

Abdelhadi, S. O., Dosoretz, C. G., Rytwo, G., Gerchman, Y., \& Azaizeh, H. (2017). Production of biochar from olive mill solid waste for heavy metal removal. Bioresource Technology, 244, 759-767. https://doi.org/10.1016/j.biortech.2017.08.013

Al Afif, R., \& Linke, B. (2019). Biogas production from three-phase olive mill solid waste in lab-scale continuously stirred tank reactor. Energy, 171, 1046-1052. https://doi.org/10.1016/j.energy.2019. 01.080

Al-Addous, M., Alnaief, M., Class, C., Nsair, A., Kuchta, K., \& Alkasrawi, M. (2017). Technical possibilities of biogas production from olive and date waste in Jordan. BioResources, 12(4), 9383-9395. https://doi.org/10.15376/biores.12.4.9383-9395

Alipieva, K., Korkina, L., Orhan, I. E., \& Georgiev, M. I. (2014). Verbascoside - A review of its occurrence, (bio)synthesis and pharmacological significance. Biotechnology Advances, 32(6), 10651076. https://doi.org/10.1016/j.biotechadv.2014.07.001

Al-Khatib, A., Aqra, F., Al-Jabari, M., Yaghi, N., Basheer, S., Sabbah, I., B. Al-Hayek, \& Mosa, M. (2009). Environmental pollution resulting from olive oil production. Bulgarian Journal of Agricultural Science, 15(6), 544-551.

Anastopoulos, I., Massas, I., \& Ehaliotis, C. (2015). Use of residues and by-products of the olive-oil production chain for the removal of pollutants from environmental media: A review of batch biosorption approaches. Journal of Environmental Science and Health - Part A Toxic/Hazardous Substances and Environmental Engineering, 50(7), 677-718. https://doi.org/10.1080/10934529.2015. 1011964

Annunziata, G., Maisto, M., Schisano, C., Barrea, L., Ciampaglia, R., Narciso, V., Tenore, G. C., \& Novellino, E. (2018). Oleuropein as a novel anti-diabetic nutraceutical. An overview. Archives of Diabetes \& Obesity, 1(3), 54-58. https://doi.org/10.32474/ado.2018.01. 000113

Anter, J., Tasset, I., Demyda-Peyrás, S., Ranchal, I., Moreno-Millán, M., Romero-Jimenez, M., Muntané, J., de Castro, M. D. L., MuñozSerrano, A., \& Alonso-Moraga, Á. (2014). Evaluation of potential antigenotoxic, cytotoxic and proapoptotic effects of the olive oil by-product "alperujo", hydroxytyrosol, tyrosol and verbascoside. Mutation Research - Genetic Toxicology and Environmental Mutagenesis, 772, 25-33. https://doi.org/10.1016/j.mrgentox.2014.07.002

Araújo, M., Pimentel, F. B., Alves, R. C., \& Oliveira, M. B. P. P. (2015). Phenolic compounds from olive mill wastes: Health effects, analytical approach and application as food antioxidants. Trends in Food Science and Technology, 45(2), 200-211. https://doi.org/10.1016/j. tifs.2015.06.010

Arche, M. A. F., García Gimenez, M. D., Martín, M. A., Guerreo, A. M. Q., \& Martínez, J. M. Z. (2019). ES 2734600 A1. Aloe and hydroxytyrosol gel composition.

Arvanitoyannis, I. S., \& Kassaveti, A. (2007). Current and potential uses of composted olive oil waste. International Journal of Food Science and Technology, 42(3), 281-295. https://doi.org/10.1111/j. 1365-2621.2006.01211.x 
Azbar, N., Bayram, A., Filibeli, A., Muezzinoglu, A., Sengul, F., \& Ozer, A. (2004). A review of waste management options in olive oil production. Critical Reviews in Environmental Science and Technology, 34(3), 209-247. https://doi.org/10.1080/10643380490279932

Balzan, S., Taticchi, A., Cardazzo, B., Urbani, S., Servili, M., Di Lecce, G., Zabalza, I. B., Rodriguez-Estrada, Novelli, E., , \& Fasolato, L. (2017). Effect of phenols extracted from a by-product of the oil mill on the shelf-life of raw and cooked fresh pork sausages in the absence of chemical additives. LWT - Food Science and Technology, 85, 89-95. https://doi.org/10.1016/j.lwt.2017.07.001

Battista, F., Mancini, G., Ruggeri, B., \& Fino, D. (2016). Selection of the best pretreatment for hydrogen and bioethanol production from olive oil waste products. Renewable Energy, 88, 401-407. https://doi.org/10.1016/j.renene.2015.11.055

Bedoya, L. M., Beltrán, M., Obregón-Calderón, P., García-Pérez, J., De La Torre, H. E., González, N., Pérez-Olmeda, M., Auñón, D., Capa, L., Gómez-Acebo, E., \& Alcamí, J. (2016). Hydroxytyrosol: A new class of microbicide displaying broad anti-HIV1 activity. Aids, 30(18), 2767-2776. https://doi.org/10.1097/QAD. 0000000000001283

Bernini, R., Carastro, I., Palmini, G., Tanini, A., Zonefrati, R., Pinelli, P., Brandi, M. L., \& Romani, A. (2017). Lipophilization of hydroxytyrosol-enriched fractions from Olea europaea L. byproducts and evaluation of the in vitro effects on a model of colorectal cancer cells. Journal of Agricultural and Food Chemistry, 65(31), 6506-6512. https://doi.org/10.1021/acs.jafc.6b05457

Bernini, R., Merendino, N., Romani, A., \& Velotti, F. (2013). Naturally occurring hydroxytyrosol: Synthesis and anticancer potential. Current Medicinal Chemistry, 20(5), 655-670. https://doi.org/ 10.2174/092986713804999367

Bernini, R., Montani, M. S. G., Merendino, N., Romani, A., \& Velotti, F. (2015). Hydroxytyrosol-derived compounds: A basis for the creation of new pharmacological agents for cancer prevention and therapy. Journal of Medicinal Chemistry, 58(23), 9089-9107. https://doi.org/10.1021/acs.jmedchem.5b00669

Berrougui, H., Ikhlef, S., \& Khalil, A. (2015). Extra virgin olive oil polyphenols promote cholesterol efflux and improve HDL functionality. Evidence-Based Complementary and Alternative Medicine, 2015, 208062. https://doi.org/10.1155/2015/208062

Bertelli, M., Kiani, A. K., Paolacci, S., Manara, E., Kurti, D., Dhuli, K., Bushati, V., Miertus, J., Pangallo, D., Baglivo, M., Beccari, T., \& Michelini, S. (2020). Hydroxytyrosol: A natural compound with promising pharmacological activities. Journal of Biotechnology, 309, 29-33. https://doi.org/10.1016/j.jbiotec.2019.12.016

Bhatnagar, A., Kaczala, F., Hogland, W., Marques, M., Paraskeva, C. A., Papadakis, V. G., \& Sillanpää, M. (2014). Valorization of solid waste products from olive oil industry as potential adsorbents for water pollution control-a review. Environmental Science and Pollution Research, 21, 268-298. https://doi.org/10.1007/ s11356-013-2135-6

Bisignano, C., Filocamo, A., Ginestra, G., Giofre', S. V., Navarra, M., Romeo, R., \& Mandalari, G. (2014). 3,4-DHPEA-EA from Olea Europaea L. is effective against standard and clinical isolates of Staphylococcus sp. Annals of Clinical Microbiology and Antimicrobials, 13(1), 24. https://doi.org/10.1186/1476-0711-13-24

Boutry, C., Breuille, D. \& Horcajada, N. (2020). US Patent 2020/0390793 A1. Compositions and methods using oleuropein or curcumin for muscle quality and/or muscle mass. Issued May 31, 2019.
Bulbarello, A. \& Leuthardt, K. (2016). Patent WO 2016/087428 A1. Fortification of edible oils with hydroxytyrosol. Issued June 9, 2016.

Bulotta, S., Celano, M., Lepore, S. M., Montalcini, T., Pujia, A., \& Russo, D. (2014). Beneficial effects of the olive oil phenolic components oleuropein and hydroxytyrosol: Focus on protection against cardiovascular and metabolic diseases. Journal of Translational Medicine, 12, 219. https://doi.org/10.1186/s12967-014-0219-9

Caballero, A. S., Romero-García, J. M., Castro, E., \& Cardona, C. A. (2020). Supercritical fluid extraction for enhancing polyphenolic compounds production from olive waste extracts. Journal of Chemical Technology and Biotechnology, 95(2), 356-362. https://doi.org/10.1002/jctb.5907

Caporaso, N., Formisano, D., \& Genovese, A. (2018). Use of phenolic compounds from olive mill wastewater as valuable ingredients for functional foods. Critical Reviews in Food Science and Nutrition, 58(16), 2829-2841. https://doi.org/10.1080/10408398.2017. 1343797

Cardinali, A., Pati, S., Minervini, F., D’Antuono, I., Linsalata, V., \& Lattanzio, V. (2012). Verbascoside, isoverbascoside, and their derivatives recovered from olive mill wastewater as possible food antioxidants. Journal of Agricultural and Food Chemistry, 60(7), 1822-1829. https://doi.org/10.1021/jf204001p

Cardoso, S. M., Guyot, S., Marnet, N., Lopes-da-Silva, J. A., Renard, C. M. G. C., \& Coimbra, M. A. (2005). Characterisation of phenolic extracts from olive pulp and olive pomace by electrospray mass spectrometry. Journal of the Science of Food and Agriculture, 85(1), 21-32. https://doi.org/10.1002/jsfa.1925

Casamassima, D. (2013). Patent WO 2013/084249 A1. Dietary supplement comprising verbascoside and teupolioside for lowering LDL and increasing HDL. Issued June 13, 2013.

Casamenti, F., Grossi, C., Rigacci, S., Pantano, D., Luccarini, I., \& Stefani, M. (2015). Oleuropein aglycone: A possible drug against degenerative conditions. In vivo evidence of its effectiveness against Alzheimer's disease. Journal of Alzheimer's Disease, 45(3), 679-688. https://doi.org/10.3233/JAD-142850

Cedola, A., Cardinali, A., D’Antuono, I., Conte, A., \& Del Nobile, M. A. (2020). Cereal foods fortified with by-products from the olive oil industry. Food Bioscience, 33, 100490. https://doi.org/10.1016/j. fbio.2019.100490

Cedola, A., Palermo, C., Centonze, D., Del Nobile, M. A., \& Conte, A. (2020). Characterization and bio-accessibility evaluation of olive leaf extract-enriched "Taralli. Foods, 9, 1268. https://doi.org/10. 3390/foods9091268

Čepo, D. V., Radić, K., Jurmanović, S., Jug, M., Rajković, M. G., Pedisić, S., Moslavac, T., \& Albahari, P. (2018). Valorization of olive pomace-based nutraceuticals as antioxidants in chemical, food, and biological models. Molecules, 23(8), 2070. https://doi.org/10. 3390/molecules 23082070

Chandramohan, R., \& Pari, L. (2016). Anti-inflammatory effects of tyrosol in streptozotocin-induced diabetic Wistar rats. Journal of Functional Foods, 27, 17-28. https://doi.org/10.1016/j.jff.2016.08. 043

Chanioti Sofia, \& Tzia Constantina. (2018). Extraction of phenolic compounds from olive pomace by using natural deep eutectic solvents and innovative extraction techniques. Innovative Food Science \& Emerging Technologies, 48, 228-239. https://doi.org/10. 1016/j.ifset.2018.07.001

Chaves-López, C., Serio, A., Mazzarrino, G., Martuscelli, M., Scarpone, E., \& Paparella, A. (2015). Control of household mycoflora 
in fermented sausages using phenolic fractions from olive mill wastewaters. International Journal of Food Microbiology, 207, 4956. https://doi.org/10.1016/j.ijfoodmicro.2015.04.040

Chen, C. H., Lin, Y. S., Chien, M. Y., Hou, W. C., \& Hu, M. L. (2012). Antioxidant and antihypertensive activities of acteoside and its analogs. Botanical Studies, 53(4), 421-429.

Cioffi, G., Pesca, M. S., De Caprariis, P., Braca, A., Severino, L., \& De Tommasi, N. (2010). Phenolic compounds in olive oil and olive pomace from Cilento (Campania, Italy) and their antioxidant activity. Food Chemistry, 121(1), 105-111. https://doi.org/10.1016/j. foodchem.2009.12.013

Codina, E. G. \& Monjo, E. G. (2014). Patent ES2462565 A1. Uso dermocosmético del hidroxitirosol para aclarar la piel y composiciones que lo comprenden. Issued March 4, 2015.

Cordero, J. G., García-Escudero, R., Avila, J., Gargini, R., \& GarcíaEscudero, V. (2018). Benefit of oleuropein aglycone for Alzheimer's disease by promoting autophagy. Oxidative Medicine and Cellular Longevity, 2018, 5010741. https://doi.org/10.1155/2018/5010741

Crea, R. (2014). US Patent 2014/0011756 A1. Method for treatment of inflammation. Issued January 9, 2014.

Crea, R. (2017). US Patent 2017/0367995 A1. Treatment of early stage Parkinson's disease with a hydroxytyrosol-containing polyphenol formulation. Issued June 23, 2016.

Cui, Q., Pan, Y., Zhang, W., Zhang, Y., Ren, S., Wang, D., Wang, Z., Liu, X., \& Xiao, W. (2018). Metabolites of dietary acteoside: Profiles, isolation, identification, and hepatoprotective capacities. Journal of Agricultural and Food Chemistry, 66(11), 2660-2668. https://doi. org/10.1021/acs.jafc.7b04650

D’Angelo, S., Ingrosso, D., Migliardi, V., Sorrentino, A., Donnarumma, G., Baroni, A., Masella, L., Tufano, M. A., Zappia, M., \& Galletti, P. (2005). Hydroxytyrosol, a natural antioxidant from olive oil, prevents protein damage induced by long-wave ultraviolet radiation in melanoma cells. Free Radical Biology and Medicine, 38(7), 908-919. https://doi.org/10.1016/j.freeradbiomed. 2004.12.015

de la Casa José A., \& Castro Eulogio. (2014). Recycling of washed olive pomace ash for fired clay brick manufacturing. Construction and Building Materials, 61, 320-326. https://doi.org/10.1016/ j.conbuildmat.2014.03.026

de la Casa, J. A., Lorite, M., Jiménez, J., \& Castro, E. (2009). Valorisation of wastewater from two-phase olive oil extraction in fired clay brick production. Journal of Hazardous Materials, 169(1-3), 271-278. https://doi.org/10.1016/j.jhazmat.2009.03.095

de Magalhães Nunes da Ponte, M. L., dos Santos, J. L. C., Matias, A. A. F., Nunes, A. V. M. N., Duarte, C. M. M. \& Crespo, J. P. S. G. (2014). Patent EP1910257 B1. Method of obtaining a natural hydroxytyrosol-rich concentrate from olive tree residues and subproducts using clean technologies. Issued January 1, 2014.

de Moraes Crizel Tainara, de Oliveira Rios Alessandro, D. Alves Vítor, Bandarra Narcisa, Moldão-Martins Margarida, \& Hickmann Flôres Simone. (2018). Active food packaging prepared with chitosan and olive pomace. Food Hydrocolloids, 74, 139-150. https: //doi.org/10.1016/j.foodhyd.2017.08.007

de Moura Sperotto, N. D., Steffens, L., Veríssimo, R. M., Henn, J. G., Péres, V. F., Vianna, P., Chies, J. A. B., Roehe, A., Saffi, J., \& Moura, D. J. (2018). Wound healing and anti-inflammatory activities induced by a Plantago australis hydroethanolic extract standardized in verbascoside. Journal of Ethnopharmacology, 225, 178188. https://doi.org/10.1016/j.jep.2018.07.012
Dermeche, S., Nadour, M., Larroche, C., Moulti-Mati, F., \& Michaud, P. (2013). Olive mill wastes: Biochemical characterizations and valorization strategies. Process Biochemistry, 48(10), 1532-1552. https://doi.org/10.1016/j.procbio.2013.07.010

Drira, R., Chen, S., \& Sakamoto, K. (2011). Oleuropein and hydroxytyrosol inhibit adipocyte differentiation in 3 T3-L1 cells. Life Sciences, 89(19-20), 708-716. https://doi.org/10.1016/j.lfs.2011.08.012

Dunne, G. (2019). Transforming olive waste into animal feed. International Journal of Clinical Nutrition \& Dietetics, 5(142), 10-12. https://doi.org/10.15344/2456-8171/2019/142

EFSA Panel on Dietetic Products Nutrition and Allergies. (2011). Scientific Opinion on the substantiation of health claims related to polyphenols in olive and protection of LDL particles from oxidative damage (ID 1333, 1638, 1639, 1696, 2865), maintenance of normal blood HDL cholesterol concentrations (ID 1639), mainte. EFSA Journal, 9(4), 2033. https://doi.org/10.2903/j.efsa.2011.2033

EFSA Panel on Dietetic Products Nutrition and Allergies. (2017). Safety of hydroxytyrosol as a novel food pursuant to Regulation (EC) No 258/97. EFSA Journal, 15(3), e04728. https://doi.org/10. 2903/j.efsa.2017.4728

Ehrenberger, K. \& Bieberschulte, W. (2011). Patent WO 2011/153647 A1. Pharmaceutical composition with olive extract (hydroxytyrosol) and hop extract (xanthohumol) for intranasal application. Issued December 15, 2011.

El-Abbassi, A., Kiai, H., \& Hafidi, A. (2012). Phenolic profile and antioxidant activities of olive mill wastewater. Food Chemistry, 132(1), 406-412. https://doi.org/10.1016/j.foodchem.2011.11.013

Claude Elama, Mohammed Tarawa, \& Fuad Al-Rimawi. (2017). Oleuropein from Olive Leaf Extract as Natural Antioxidant of Frozen Hamburger. Journal of Food Science and Engineering, 7(8), https://doi.org/10.17265/2159-5828/2017.08.005

Eliche-Quesada, D., Iglesias-Godino, F. J., Pérez-Villarejo, L., \& Corpas-Iglesias, F. A. (2014). Replacement of the mixing fresh water by wastewater olive oil extraction in the extrusion of ceramic bricks. Construction and Building Materials, 68, 659-666. https: //doi.org/10.1016/j.conbuildmat.2014.07.017

El-Marasy, S. A., El-Shenawy, S. M., Moharram, F. A., \& ElSherbeeny, N. A. (2020). Antidiabetic and antioxidant effects of acteoside from Jacaranda mimosifolia family Biognoniaceae in Streptozotocin-Nicotinamide induced diabetes in rats. Open Access Macedonian Journal of Medical Sciences, 8, 125-133. https://doi.org/10.3889/OAMJMS.2020.3325

Estaún, J., Dosil, J., Al Alami, A., Gimeno, A., \& de Vega, A. (2014). Effects of including olive cake in the diet on performance and rumen function of beef cattle. Animal Production Science, 54(10), 1817. https://doi.org/10.1071/an14352

Federici, E., Massaccesi, L., Pezzolla, D., Fidati, L., Montalbani, E., Proietti, P., Nasini, L., Regni, L., Scargetta, S., \& Gigliotti, G. (2017). Short-term modifications of soil microbial community structure and soluble organic matter chemical composition following amendment with different solid olive mill waste and their derived composts. Applied Soil Ecology, 119, 234-241. https://doi. org/10.1016/j.apsoil.2017.06.014

Fernández-González, R., Martín-Lara, M. Á., Blázquez, G., Pérez, A., \& Calero, M. (2019). Recovering metals from aqueous solutions by biosorption onto hydrolyzed olive cake. Water, 11(12), 2519. https://doi.org/10.3390/w11122519

Fernández-Hernández, A., Roig, A., Serramiá, N., Civantos, C. G. O., \& Sánchez-Monedero, M. A. (2014). Application of compost 
of two-phase olive mill waste on olive grove: Effects on soil, olive fruit and olive oil quality. Waste Management, 34(7), 1139-1147. https://doi.org/10.1016/j.wasman.2014.03.027

Fernando Ana, Monteiro Sofia, Pinto Filomena, \& Mendes Benilde. (2009). Production of Biosorbents from Waste Olive Cake and Its Adsorption Characteristics for Zn2+ Ion. Sustainability, 1(2), 277297. https://doi.org/10.3390/su1020277

Filip, R., Possemiers Sam, Heyerick, A., Pinheiro, I., Raszewski, G., Davicco, M.-J., \& Coxam V. (2015). Twelve-month consumption of a polyphenol extract from olive (Olea europaea) in a double blind, randomized trial increases serum total osteocalcin levels and improves serum lipid profiles in postmenopausal women with osteopenia. The journal of nutrition, health \& aging, 19(1), 77-86. https://doi.org/10.1007/s12603-014-0480-X

Fiorentino, A., Gentili, A., Isidori, M., Monaco, P., Nardelli, A., Parrella, A., \& Temussi, F. (2003). Environmental effects caused by olive mill wastewaters: Toxicity comparison of low-molecularweight phenol components. Journal of Agricultural and Food Chemistry, 51(4), 1005-1009. https://doi.org/10.1021/jf020887d

Fki, I., Sayadi, S., Mahmoudi, A., Daoued, I., Marrekchi, R., \& Ghorbel, H. (2020). Comparative study on beneficial effects of hydroxytyrosol- and oleuropein-rich olive leaf extracts on highfat diet-induced lipid metabolism disturbance and liver injury in rats. BioMed Research International, 2021, 1315202. https://doi.org/ 10.1155/2020/1315202

Funes, L., Fernández-Arroyo, S., Laporta, O., Pons, A., Roche, E., Segura-Carretero, A., A. Fernández-Gutiérrez, \& Micol, V. (2009). Correlation between plasma antioxidant capacity and verbascoside levels in rats after oral administration of lemon verbena extract. Food Chemistry, 117(4), 589-598. https://doi.org/10.1016/j. foodchem.2009.04.059

Funes, L., Laporta, O., Cerdán-Calero, M., \& Micol, V. (2010). Effects of verbascoside, a phenylpropanoid glycoside from lemon verbena, on phospholipid model membranes. Chemistry and Physics of Lipids, 163(2), 190-199. https://doi.org/10.1016/j.chemphyslip. 2009.11.004

Fuwa, T., Nakao, Y. \& Matsubayashi, H. (2019). US Patent 2019/012952 A1. Beverage containing hydroxytyrosol. Issued October 08, 2019.

Galanakis, Charis M. (2018). Phenols recovered from olive mill wastewater as additives in meat products. Trends in Food Science \& Technology, 79, 98-105. https://doi.org/10.1016/j.tifs.2018.07.010

Galanakis, Charis M. (2020). The Food Systems in the Era of the Coronavirus (COVID-19) Pandemic Crisis. Foods, 9(4), 523. https: //doi.org/10.3390/foods9040523

Galanakis, C. M., Aldawoud, T. M. S., Rizou, M., Rowan, N. J., \& Ibrahim, S. A. (2020). Food ingredients and active compounds against the coronavirus disease (COVID-19) pandemic: A comprehensive review. Foods, 9(11), 1701. https://doi.org/10.3390/ foods 9111701

Galanakis, Charis M., Rizou Myrto, Aldawoud, Turki M. S., Ucak Ilknur, \& Rowan, Neil J. (2021). Innovations and technology disruptions in the food sector within the COVID-19 pandemic and post-lockdown era. Trends in Food Science \& Technology, 110, 193200. https://doi.org/10.1016/j.tifs.2021.02.002

Galanakis, Charis M., Tsatalas Philippos, Charalambous, Zina, \& Galanakis, Ioannis M. (2018). Control of microbial growth in bakery products fortified with polyphenols recovered from olive mill wastewater. Environmental Technology \& Innovation, 10, 1-15. https://doi.org/10.1016/j.eti.2018.01.006
Galanakis Charis M., Tsatalas Philippos, Galanakis Ioannis M. (2018). Implementation of phenols recovered from olive mill wastewater as UV booster in cosmetics. Industrial Crops and Products, 111, 3037. https://doi.org/10.1016/j.indcrop.2017.09.058

Georgakouli, K., Mpesios, A., Kouretas, D., Petrotos, K., Mitsagga, C., Giavasis, I., \& Jamurtas, A. Z. (2016). The effects of an olive fruit polyphenol-enriched yogurt on body composition, blood redox status, physiological and metabolic parameters and yogurt microflora. Nutrients, 8(344), 1-14. https://doi.org/10.3390/ nu8060344

Gerasopoulos, K., Stagos, D., Kokkas, S., Petrotos, K., Kantas, D., Goulas, P., \& Kouretas, D. (2015). Feed supplemented with byproducts from olive oil mill wastewater processing increases antioxidant capacity in broiler chickens. Food and Chemical Toxicology, 82, 42-49. https://doi.org/10.1016/j.fct.2015.04.021

Gerasopoulos, K., Stagos, D., Petrotos, K., Kokkas, S., Kantas, D., Goulas, P., \& Kouretas, D. (2015). Feed supplemented with polyphenolic byproduct from olive mill wastewater processing improves the redox status in blood and tissues of piglets. Food and Chemical Toxicology, 86, 319-327. https://doi.org/10.1016/j.fct.2015. 11.007

Giovannini, C., Straface, E., Modesti, D., Coni, E., Cantafora, A., De Vincenzi, M., Malorni, W., \& Masella, R. (1999). Tyrosol, the major olive oil biophenol, protects against oxidized-LDLinduced injury in Caco-2 cells. Journal of Nutrition, 129, 1269-1277. https://doi.org/10.1093/jn/129.7.1269

Goldsmith, Chloe D., Vuong, Quan V., Stathopoulos, Costas E., Roach, Paul D., Scarlett, \& Christopher J. (2018). Ultrasound increases the aqueous extraction of phenolic compounds with high antioxidant activity from olive pomace. $L W T, 89,284-290$. https://doi.org/10.1016/j.lwt.2017.10.065

Gómez-Acebo, E., Pertejo, J. A. \& Calles, D. A. (2012). US Patent 2012/0260922 A1. Topical use of hydroxytyrosol and derivatives for the prevention of HIV infection. Issued October 10, 2012.

Grossi, C., Rigacci, S., Ambrosini, S., Ed Dami, T., Luccarini, I., Traini, C., Failli, P., Berti, A., Casamenti, F., \& Stefani, M. (2013). The polyphenol oleuropein aglycone protects TgCRND8 mice against Aß plaque pathology. Plos One, 8(8), e71702. https://doi. org/10.1371/journal.pone.0071702

Guglielmotti, M., Passaghe, P., \& Buiatti, S. (2020). Use of olive (Olea europaea L.) leaves as beer ingredient, and their influence on beer chemical composition and antioxidant activity. Journal of Food Science, 85(8), 2278-2285. https://doi.org/10.1111/1750-3841.15318

Gusman, J. F.-B., Moreno, A. H., Gutierrez, G. R., Arcos, R. R., Araujo, A. J. \& Bejarano, R. G. (2005). US Patent 6849770 B2. Method for obtaining purified hydroxytyrosol from products and by-products derived from the olive tree. Issued February 01, 2005.

Hagiwara, K., Goto, T., Araki, M., Miyazaki, H., \& Hagiwara, H. (2011). Olive polyphenol hydroxytyrosol prevents bone loss. European Journal of Pharmacology, 662(1-3), 78-84. https://doi.org/10. 1016/j.ejphar.2011.04.023

Hassen, I., Casabianca, H., \& Hosni, K. (2015). Biological activities of the natural antioxidant oleuropein: Exceeding the expectation - A mini-review. Journal of Functional Foods, 18, 926-940. https://doi.org/10.1016/j.jff.2014.09.001

Illesca, P., Valenzuela, R., Espinosa, A., Echeverría, F., SotoAlarcon, S., Ortiz, M., \& Videla, L. A. (2019). Hydroxytyrosol supplementation ameliorates the metabolic disturbances in white adipose tissue from mice fed a high-fat diet through 
recovery of transcription factors Nrf2, SREBP-1c, PPAR- $\gamma$ and NF$\kappa \mathrm{B}$. Biomedicine and Pharmacotherapy, 109, 2472-2481. https://doi. org/10.1016/j.biopha.2018.11.120

Imran, M., Nadeem, M., Gilani, S. A., Khan, S., Sajid, M. W., \& Amir, R. M. (2018). Antitumor perspectives of oleuropein and its metabolite hydroxytyrosol: Recent updates. Journal of Food Science, 83(7), 1781-1791. https://doi.org/10.1111/1750-3841.14198

Jemai, H., Bouaziz, M., Fki, I., El Feki, A., \& Sayadi, S. (2008). Hypolipidimic and antioxidant activities of oleuropein and its hydrolysis derivative-rich extracts from Chemlali olive leaves. ChemicoBiological Interactions, 176(2-3), 88-98. https://doi.org/10.1016/j. cbi.2008.08.014

Jeon Seeun, Choi Mina. (2018). Anti-inflammatory and antiaging effects of hydroxytyrosol on human dermal fibroblasts (HDFs). Biomedical Dermatology, 2(1), https://doi. org/10.1186/s41702-018-0031-x

Khdair, A. I., Abu-Rumman, G., \& Khdair, S. I. (2019). Pollution estimation from olive mills wastewater in Jordan. Heliyon, 5(8), e02386. https://doi.org/10.1016/j.heliyon.2019.e02386

Khemakhem, I., Fuentes, A., Lerma-García, M. J., Ayadi, M. A., Bouaziz, M., \& Barat, J. M. (2019). Olive leaf extracts for shelf life extension of salmon burgers. Food Science and Technology International, 25(2), 91-100. https://doi.org/10.1177/1082013218795816

Kim, S. W., Hur, W., Li, T. Z., Lee, Y. K., Choi, J. E., Hong, S. W., Lyoo, K. S., You, C. R., Jung, E. S., Jung, C. K., Park, T., Um, S. J., \& Yoon, S. K. (2014). Oleuropein prevents the progression of steatohepatitis to hepatic fibrosis induced by a high-fat diet in mice. Experimental and Molecular Medicine, 46(4), e2. https://doi.org/10.1038/emm. 2014.10

Kimura, Y., \& Sumiyoshi, M. (2009). Olive leaf extract and its main component oleuropein prevent chronic ultraviolet B radiationinduced skin damage and carcinogenesis in hairless mice. The Journal of Nutrition, 139(11), 2079-2086. https://doi.org/10.3945/jn. 109.104992

Koc, K., Cerig, S., Ucar, S., Colak, S., Bakir, M., Erol, H. S., Yildirim, S., Hosseinigouzdagani, M., Simsek Ozek, N., Aysin, F., Fehim Kocpinar, E., Budak, H., \& Geyikoglu, F. (2018). Gastroprotective effects of oleuropein and thymol on indomethacin-induced gastric ulcer in Sprague-Dawley rats. Drug and Chemical Toxicology, 43(5), 441-453. https://doi.org/10.1080/01480545.2018.1530261

Kumari, D., \& Singh, R. (2018). Pretreatment of lignocellulosic wastes for biofuel production: A critical review. Renewable and Sustainable Energy Reviews, 90, 877-891. https://doi.org/10.1016/j.rser. 2018.03.111

Lammi, S., Le Moigne, N., Djenane, D., Gontard, N., \& AngellierCoussy, H. (2018). Dry fractionation of olive pomace for the development of food packaging biocomposites. Industrial Crops and Products, 120, 250-261. https://doi.org/10.1016/j.indcrop.2018.04. 052

Lee Kwang Min, Hur Jinyoung, Lee Yeonmi, Yoon Bo-Ra, Choi Sang Yoon (2018). Protective Effects of Tyrosol Against Oxidative Damage in L6 Muscle Cells. Food Science and Technology Research, 24(5), 943-947. https://doi.org/10.3136/fstr.24.943

Sylvia Lee-Huang, Paul L. Huang, Philip Lin Huang, Dawei Zhang, John Z. H. Zhang, Young Tae Chang, Jae Wook Lee, Ju Bao, Yongtao Sun (2013). US 8574635 B2. Compositions and methods for treating obesity, obesity related disorders and for inhibiting the infectivity of human immunodeficiency virus. Issued November 05, 2013.
Lee-Huang, S., Huang, P. L., Zhang, D., Lee, J. W., Bao, J., Sun, Y., Chang, Y. T., Zhang, J., \& Huang, P. L. (2007). Discovery of smallmolecule HIV-1 fusion and integrase inhibitors oleuropein and hydroxytyrosol: Part I. Integrase inhibition. Biochemical and Biophysical Research Communications, 354, 872-878. https://doi.org/ 10.1016/j.bbrc.2007.01.071

Lee-Huang, S., Zhang, L., Huang, P. L., Chang, Y. T., \& Huang, P. L. (2003). Anti-HIV activity of olive leaf extract (OLE) and modulation of host cell gene expression by HIV-1 infection and OLE treatment. Biochemical and Biophysical Research Communications, 307(4), 1029-1037. https://doi.org/10.1016/S0006-291X(03) 01292-0

Leenen, R., Roodenburg, A. J. C., Vissers, M. N., Schuurbiers, J. A. E., Van Putte, K. P. A. M., Wiseman, S. A., \& Van de Put, F. H. M. M. (2002). Supplementation of plasma with olive oil phenols and extracts: Influence on LDL oxidation. Journal of Agricultural and Food Chemistry, 50(5), 1290-1297. https://doi.org/10. 1021/jf010968u

Leouifoudi, I., Mbarki, M., Tilaoui, M., Amechrouq, A., Mostapha, E., Mouse, H. A., \& Zyad, A. (2014). Study of the in vitro anticancer activity of Moroccan phenolic olive cake extracts. Journal of Pharmacognosy and Phytochemistry, 2(6), 154-165.

Leri, M., \& Bucciantini, M. (2016). Efficacy of oleuropein aglycone in the treatment of transthyretin-amyloidosis. Biochemistry \& Molecular Biology Journal, 2(1), 1-6. https://doi.org/10.21767/2471-8084. 100011

Li, X., Liu, Y., Jia, Q., LaMacchia, V., O’Donoghue, K., \& Huang, Z. (2016). A systems biology approach to investigate the antimicrobial activity of oleuropein. Journal of Industrial Microbiology and Biotechnology, 43(12), 1705-1717. https://doi.org/10.1007/ s10295-016-1841-8

Liu, M., Yong, Q., \& Yu, S. (2018). Efficient bioconversion of oleuropein from olive leaf extract to antioxidant hydroxytyrosol by enzymatic hydrolysis and high-temperature degradation. Biotechnology and Applied Biochemistry, 65(5), 680-689. https://doi.org/ 10.1002/bab.1651

Liu, Y. H., Lu, Y. L., Han, C. H., \& Hou, W. C. (2013). Inhibitory activities of acteoside, isoacteoside, and its structural constituents against protein glycation in vitro. Botanical Studies, 54(1), 6. https://doi.org/10.1186/1999-3110-54-6

Liu, Y., McKeever, L. C., \& Malik, N. S. A. (2017). Assessment of the antimicrobial activity of olive leaf extract against foodborne bacterial pathogens. Frontiers in Microbiology, 8, 113. https://doi.org/10. 3389/fmicb.2017.00113

Loru, D., Incani, A., Deiana, M., Corona, G., Atzeri, A., Melis, M., Rosa, A., \& Dessì, M. (2009). Protective effect of hydroxytyrosol and tyrosol against oxidative stress in kidney cells. Toxicology and Industrial Health, 25(5), 301-310. https://doi.org/10.1177/ 0748233709103028

Ma, D., Wang, J., Liu, L., Chen, M., \& Wang, Z. (2020). Acteoside as a potential therapeutic option for primary hepatocellular carcinoma: A preclinical study. BMC Cancer, 20(1), 936. https://doi. org/10.1186/s12885-020-07447-3

Madureira, J., Dias, M. I., Pinela, J., Calhelha, R. C., Barros, L., SantosBuelga, C., Margaça, F. M. A., Ferreira I., \& Verde, S. C. (2020). The use of gamma radiation for extractability improvement of bioactive compounds in olive oil wastes. Science of the Total Environment, 727, 138706. https://doi.org/10.1016/j.scitotenv.2020. 138706 
Majbar Z., Lahlou, K., Ben, Abbou M., Ammar, E., Triki, A., Abid, W., Nawdali, M., Bouka, H., Taleb, M., El Haji, M., \& Rais, Z. (2018). Co-composting of Olive Mill Waste and Wine-Processing Waste: An Application of Compost as Soil Amendment. Journal of Chemistry, 2018, 1-9. https://doi.org/10.1155/2018/7918583

Malapert, A., Reboul, E., Loonis, M., Dangles, O., \& Tomao, V. (2018). Direct and rapid profiling of biophenols in olive pomace by UHPLC-DAD-MS. Food Analytical Methods, 11(4), 1001-1010. https://doi.org/10.1007/s12161-017-1064-2

Marković, A. K., Torić, J., Barbarić, M., \& Brala, C. J. (2019). Hydroxytyrosol, tyrosol and derivatives and their potential effects on human health. Molecules, 24(10), 2001. https://doi.org/10.3390/ molecules24102001

Martín, L. C., Tirado, F. J. S. \& Antoñanzas, Y. A. (2007). Patent WO 2007/051829 A1. Oleuropein for the treatment of conditions associated to the peripheral vascular disease. Issued May 10, 2007.

Martínez, L., Castillo, J., Ros, G., \& Nieto, G. (2019). Antioxidant and antimicrobial activity of rosemary, pomegranate and olive extracts in fish patties. Antioxidants, 8(4), 86. https://doi.org/10. 3390/antiox8040086

Martinez-Garcia, G., Bachmann, Robert Th., Williams, Ceri J., Burgoyne, Andrea, Edyvean, Robert G. J. (2006). Olive oil waste as a biosorbent for heavy metals. International Biodeterioration \& Biodegradation, 58(3-4), 231-238. https://doi.org/10.1016/j.ibiod. 2006.06.028

Martín-Lara M. A., Blázquez G., Ronda A., Pérez A., \& Calero M. (2013). Development and Characterization of Biosorbents To Remove Heavy Metals from Aqueous Solutions by Chemical Treatment of Olive Stone. Industrial \& Engineering Chemistry Research, 52(31), 10809-10819. https://doi.org/10.1021/ie401246c

Más, J. L., Streitenberger, S., Penalver Mellado, M. \& Martinez Ortiz, P. (2009). Patent WO 2009/013596 A2. Fortification of nutritional products with olive extracts containing hydroxytyrosol and hydroxytyrosol fortified nutritional products. Issued January 29, 2009.

Mateos, R., Martínez-López, S., Arévalo, G. B., Amigo-Benavent, M., Sarriá, B., \& Bravo-Clemente, L. (2016). Hydroxytyrosol in functional hydroxytyrosol-enriched biscuits is highly bioavailable and decreases oxidised low density lipoprotein levels in humans. Food Chemistry, 205, 248-256. https://doi.org/10.1016/j.foodchem.2016. 03.011

Medina, E., Brenes, M., Romero, C., García, A., \& De Castro, A. (2007). Main antimicrobial compounds in table olives. Journal of Agricultural and Food Chemistry, 55(24), 9817-9823. https://doi. org/10.1021/jf0719757

Mekki, H., Anderson, M., Amar, E., Skerratt, G. R., \& Benzina, M. (2006). Olive oil mill waste water as a replacement for fresh water in the manufacture of fired clay bricks. Journal of Chemical Technology \& Biotechnology, 81, 1419-1425. https://doi.org/10.1002/jctb. 1579

Mekki, H., Anderson, M., Benzina, M., \& Ammar, E. (2008). Valorization of olive mill wastewater by its incorporation in building bricks. Journal of Hazardous Materials, 158(2-3), 308-315. https://doi.org/10.1016/j.jhazmat.2008.01.104

Menendez, J. A., Vazquez-Martin, A., Colomer, R., Brunet, J., Carrasco-Pancorbo, A., Garcia-Villalba, R., Fernandez-Gutierrez, A., \& Segura-Carretero, A. (2007). Olive oil's bitter principle reverses acquired autoresistance to trastuzumab (Herceptin ${ }^{\mathrm{TM}}$ ) in HER2-overexpressing breast cancer cells. BMC Cancer, 7, 80. https://doi.org/10.1186/1471-2407-7-80

Merra, E., Calzaretti, G., Bobba, A., Storelli, M. M., \& Casalino, E. (2014). Antioxidant role of hydroxytyrosol on oxidative stress in cadmium-intoxicated rats: Different effect in spleen and testes. Drug and Chemical Toxicology, 37(4), 420-426. https://doi.org/10. 3109/01480545.2013.878950

Messineo, A., Maniscalco, M. P., \& Volpe, R. (2020). Biomethane recovery from olive mill residues through anaerobic digestion: A review of the state of the art technology. Science of the Total Environment, 703, 135508. https://doi.org/10.1016/j.scitotenv.2019. 135508

Molina-Alcaide, E., Morales-García, E. Y., Martín-García, A. I., Salem, H. B., Nefzaoui, A., \& Sanz-Sampelayo, M. R. (2010). Effects of partial replacement of concentrate with feed blocks on nutrient utilization, microbial $\mathrm{N}$ flow, and milk yield and composition in goats. Journal of Dairy Science, 93(5), 2076-2087. https://doi.org/ 10.3168/jds.2009-2628

Morikawa, T., Ninomiya, K., Imamura, M., Akaki, J., Fujikura, S., Pan, Y., Yuan, D., Yoshikawa, M., Jia, A., Li, Z., \& Muraoka, O. (2014). Acylated phenylethanoid glycosides, echinacoside and acteoside from Cistanche tubulosa, improve glucose tolerance in mice. Journal of Natural Medicines, 68(3), 561-566. https://doi.org/ 10.1007/s11418-014-0837-9

Moudache, Messaad, Silva Filomena, Nerín Cristina, \& Zaidi, Farid. (2021). Olive cake and leaf extracts as valuable sources of antioxidant and antimicrobial compounds: a comparative study. Waste and Biomass Valorization, 12(3), 1431-1445. https://doi.org/10. 1007/s12649-020-01080-8

Muíño, I., Díaz, M. T., Apeleo, E., Pérez-Santaescolástica, C., RivasCañedo, A., Pérez, C., Cañeque, V., Lauzurica, S., \& de la Fuente, J. (2017). Valorisation of an extract from olive oil waste as a natural antioxidant for reducing meat waste resulting from oxidative processes. Journal of Cleaner Production, 140, 924-932. https://doi.org/10.1016/j.jclepro.2016.06.175

Nediani, C., Ruzzolini, J., Romani, A., \& Calorini, L. (2019). Oleuropein, a bioactive compound from olea europaea 1., as a potential preventive and therapeutic agent in non-communicable diseases. Antioxidants, 8(12), 578. https://doi.org/10.3390/antiox8120578

Nieto, G., Martínez, L., Castillo, J., \& Ros, G. (2017a). Effect of hydroxytyrosol, walnut and olive oil on nutritional profile of Low-Fat Chicken Frankfurters. European Journal of Lipid Science and Technology, 119(9), 1600518. https://doi.org/10.1002/ejlt.201600518

Nieto, G., Martínez, L., Castillo, J., \& Ros, G. (2017b). Hydroxytyrosol extracts, olive oil and walnuts as functional components in chicken sausages. Journal of the Science of Food and Agriculture, 97(11), 3761-3771. https://doi.org/10.1002/jsfa.8240

Numano, F., Crea, R., Wiedemann, T. S. \& Bitler, C. M. (2007). Patent WO 2007/012057 A2. Vegetation water composition for treatment of inflammatory skin conditions. Issued January 25, 2007.

Nunes, M. A., Costa, A. S. G., Bessada, S., Santos, J., Puga, H., Alves, R. C., Freitas, V., \& Oliveira, M. B. P. P. (2018). Olive pomace as a valuable source of bioactive compounds: A study regarding its lipid- and water-soluble components. Science of The Total Environment, 644, 229-236. https://doi.org/10.1016/j.scitotenv.2018.06. 350

Ohno, T., Inoue, M., Ogihara, Y., \& Saracoglu, I. (2002). Antimetastatic activity of acteoside, a phenylethanoid 
glycoside. Biological and Pharmaceutical Bulletin, 25(5), 666668. https://doi.org/10.1248/bpb.25.666

Oi-Kano, Y., Iwasaki, Y., Nakamura, T., Watanabe, T., Goto, T., Kawada, T., Watanabe, K., \& Iwai, K. (2017). Oleuropein aglycone enhances UCP1 expression in brown adipose tissue in high-fat-diet-induced obese rats by activating $\beta$-adrenergic signaling. Journal of Nutritional Biochemistry, 40, 209-218. https://doi. org/10.1016/j.jnutbio.2016.11.009

Pagnanelli, F., Mainelli, S., Vegliò, F., \& Toro, L. (2003). Heavy metal removal by olive pomace: Biosorbent characterisation and equilibrium modelling. Chemical Engineering Science, 58(20), 4709-4717. https://doi.org/10.1016/j.ces.2003.08.001

Palazzi, L., Bruzzone, E., Bisello, G., Leri, M., Stefani, M., Bucciantini, M., \& De Laureto, P. P. (2018). Oleuropein aglycone stabilizes the monomeric $\alpha$-synuclein and favours the growth of nontoxic aggregates. Scientific Reports, 8(1), 833. https://doi.org/10. 1038/s41598-018-26645-5

Palmeri, R., Parafati, L., Trippa, D., Siracusa, L., Arena, E., Restuccia, C., \& Fallico, B. (2019). Addition of olive leaf extract (OLE) for producing fortified fresh pasteurized milk with an extended shelf life. Antioxidants, 8(8), 255. https://doi.org/10.3390/antiox80 80255

Panyam, J. \& Chavanpatil, M. D. (2011). US Patent 2011/0144040 A1. Acteoside and Acteoside-rich plant extracts for increasing athletic performance in humans. Issued June 16, 2011.

Papaioannou, E. H., Patsios, S. I., Karabelas, A. J., \& Philippopoulos, N. A. (2013). Characterization of condensates from an indirect olive oil pomace drying process: The effect of drying temperature. Journal of Environmental Chemical Engineering, 1(4), 831837. https://doi.org/10.1016/j.jece.2013.07.025

Paulo Filipa, \& Santos Lúcia. (2020). Encapsulation of the Antioxidant Tyrosol and Characterization of Loaded Microparticles: an Integrative Approach on the Study of the Polymer-Carriers and Loading Contents. Food and Bioprocess Technology, 13(5), 764-785. https://doi.org/10.1007/s11947-020-02407-y

Paulo, F., \& Santos, L. (2020b). New insights in the in vitro release of phenolic antioxidants: The case study of the release behavior of tyrosol from tyrosol-loaded ethylcellulose microparticles during the in vitro gastrointestinal digestion. Colloids and Surfaces B: Biointerfaces, 196, 111339. https://doi.org/10.1016/j.colsurfb. 2020.111339

Pavez, I. C., Lozano-Sánchez, J., Borrás-Linares, I., Nuñez, H., Robert, P., \& Segura-Carretero, A. (2019). Obtaining an extract rich in phenolic compounds from olive pomace by pressurized liquid extraction. Molecules, 24(3108), 1-17.

Pavlidou, A., Anastasopoulou, E., Dassenakis, M., Hatzianestis, I., Paraskevopoulou, V., Simboura, N., Rousselaki, E., \& Drakopoulou, P. (2014). Effects of olive oil wastes on river basins and an oligotrophic coastal marine ecosystem: A case study in Greece. Science of the Total Environment, 497-498, 38-49. https://doi.org/10.1016/j.scitotenv.2014.07.088

Pazos, M., Alonso, A., Sánchez, I., \& Medina, I. (2008). Hydroxytyrosol prevents oxidative deterioration in foodstuffs rich in fish lipids. Journal of Agricultural and Food Chemistry, 56(9), 33343340. https://doi.org/10.1021/jf073403s

Peralbo-Molina, Á., Priego-Capote, F., \& De Castro, M. D. L. (2012). Tentative identification of phenolic compounds in olive pomace extracts using liquid chromatography-tandem mass spectrometry with a quadrupole- quadrupole-time-of-flight mass detector.
Journal of Agricultural and Food Chemistry, 60(46), 11542-11550. https://doi.org/10.1021/jf302896m

Pérez-Bonilla, M., Salido, S., Van Beek, T. A., \& Altarejos, J. (2014). Radical-scavenging compounds from olive tree (Olea europaea L.) wood. Journal of Agricultural and Food Chemistry, 62(1), 144-151. https://doi.org/10.1021/jf403998t

Perugini, P., Vettor, M., Rona, C., Troisi, L., Villanova, L., Genta, I., Conti, B., \& Pavanetto, F. (2008). Efficacy of oleuropein against UVB irradiation: Preliminary evaluation. International Journal of Cosmetic Science, 30(2), 113-120. https://doi.org/10.1111/ j.1468-2494.2008.00424.x

Pintillo, A. R. N., Konstanteli, E., Bairaktari, M. M., \& Detsi, A. (2021). Encapsulation of the natural product tyrosol in carbohydrate nanosystems and study of their binding with ctDNA. Polymers, 13, 87. https://doi.org/10.3390/polym13010087

Plotnikov, M. B., Aliev, O. I., Sidekhmenova, A. V., Shamanaev, A. Y., Anishchenko, A. M., Fomina, T. I., Plotnikova, T. M., \& Arkhipov, A. M. (2018). Effect of p-tyrosol on hemorheological parameters and cerebral capillary network in young spontaneously hypertensive rats. Microvascular Research, 119, 91-97. https://doi.org/10. 1016/j.mvr.2018.04.005

Plotnikov, M. B., Chernysheva, G. A., Smol'yakova, V. I., Maslov, M. Y., Cherkashina, I. V., Krysin, A. P., Sorokina, I. V., \& Tolstikova, T. G. (2007). Effect of n-tyrosol on blood viscosity and platelet aggregation. Bulletin of Experimental Biology and Medicine, 143(1), 6163. https://doi.org/10.1007/s10517-007-0017-y

Potapovich, A. I., Kostyuk, V. A., Kostyuk, T. V., De Luca, C., \& Korkina, L. G. (2013). Effects of pre- and post-treatment with plant polyphenols on human keratinocyte responses to solar UV. Inflammation Research, 62(8), 773-780. https://doi.org/10.1007/ s00011-013-0634-Z

Puel, C., Mardon, J., Agalias, A., Davicco, M. J., Lebecque, P., Mazur, A., Horcajada, M.-N., Skaltsounis, A.-L., \& Coxam, V. (2008). Major phenolic compounds in olive oil modulate bone loss in an ovariectomy/inflammation experimental model. Journal of Agricultural and Food Chemistry, 56(20), 9417-9422. https://doi.org/10. 1021/jf801794q

Qadir, N. M., Ali, K. A., \& Qader, S. W. (2016). Antidiabetic effect of oleuropein from Olea europaea leaf against alloxan induced type 1 diabetic in rats. Brazilian Archives of Biology and Technology, 59, e16150116. https://doi.org/10.1590/1678-4324-2016150116

Qiao, Z., Tang, J., Wu, W., Tang, J., \& Liu, M. (2019). Acteoside inhibits inflammatory response via JAK/STAT signaling pathway in osteoarthritic rats. BMC Complementary and Alternative Medicine, 19, 264. https://doi.org/10.1186/s12906-019-2673-7

Quesada-Gómez, J. M., Mora, R. M. S. \& Díaz, A. C. (2010). Patent WO 2010/070183 A1. Pharmaceutical composition comprising oleuropein for utilisation in angiogenesis and vasculogenesis induction. Issued June 24, 2010.

Quesada-Gómez, J. M., Mora, R. M. S. \& Díaz, A. C. (2011). Patent WO 2011/141611 A1. Oleuropein compositions for healing wounds and ulcers in elderly people and/or diabetics. Issued November 17, 2011.

Raederstorff, D., Schwager, J. \& Wertz, K. (2008). Patent WO 2008/128629 A1. Novel use of hydroxytyrosol. Issued October 30, 2008.

Raposo, R., Ruiz-Moreno, M. J., Garde-Cerdán, T., Puertas, B., Moreno-Rojas, J. M., Gonzalo-Diago, A., Guerrero, R. F., Ortiz, V., \& Cantos-Villar, E. (2016). Effect of hydroxytyrosol on 
quality of sulfur dioxide-free red wine. Food Chemistry, 192, 25-33. https://doi.org/10.1016/j.foodchem.2015.06.085

Raposo, R., Ruiz-Moreno, M. J., Garde-Cerdán, T., Puertas, B., Moreno-Rojas, J. M., Zafrilla, P., Gonzalo-Diago, A., Guerrero, R. F., \& Cantos-Villar, E. (2016). Replacement of sulfur dioxide by hydroxytyrosol in white wine: Influence on both quality parameters and sensory. LWT - Food Science and Technology, 65, 214-221. https://doi.org/10.1016/j.lwt.2015.08.005

Regni, L., Nasini, L., Ilarioni, L., Brunori, A., Massaccesi, L., Agnelli, A., \& Proietti, P. (2017). Long term amendment with fresh and composted solid olive mill waste on olive grove affects carbon sequestration by prunings, fruits, and soil. Frontiers in Plant Science, 7, 2042. https://doi.org/10.3389/fpls.2016.02042

Rigacci, S., Guidotti, V., Bucciantini, M., Parri, M., Nediani, C., Cerbai, E., Stefani, M., \& Berti, A. (2010). Oleuropein aglycone prevents cytotoxic amyloid aggregation of human amylin. Journal of Nutritional Biochemistry, 21(8), 726-735. https://doi.org/10.1016/j. jnutbio.2009.04.010

Rincón, B., Bujalance, L., Fermoso, F. G., Martín, A., \& Borja, R. (2013). Biochemical methane potential of two-phase olive mill solid waste: Influence of thermal pretreatment on the process kinetics. Bioresource Technology, 140, 249-255. https://doi.org/10. 1016/j.biortech.2013.04.090

Robin, J.-R. \& Rolland, Y. (2004). Patent WO 2004/069218 A1. Use of verbascoside as a stimulant agent for the production of thermal shock proteins by the cells of the skin. Issued August 19, 2004.

Rodrigues, F., da Mota Nunes, M. A. , \& Oliveira, M. B. P. P. (2017). Applications of recovered bioactive compounds in cosmetics and health care products. In Olive mill waste: Recent advances for sustainable management (pp. 255-274). Elsevier Inc. https://doi.org/ 10.1016/B978-0-12-805314-0.00012-1

Rodrigues Francisca, Pimentel, Filipa B., Oliveira, M., \& Beatriz, P. P. (2015). Olive by-products: Challenge application in cosmetic industry. Industrial Crops and Products, 70, 116-124. https://doi. org/10.1016/j.indcrop.2015.03.027

Roig, A., Cayuela, M. L., \& Sánchez-Monedero, M. A. (2006). An overview on olive mill wastes and their valorisation methods. Waste Management, 26, 960-969. https://doi.org/10.1016/j. wasman.2005.07.024

Rojas-Cano, M. L., Ruiz-Guerrero, V., Lara, L., Nieto, R., \& Aguilera J. F. (2014). Digestibility and energy value of diets containing increasing proportions of olive soapstocks for Iberian crossbred pigs. Animal Feed Science and Technology, 191, 83-90. https: //doi.org/10.1016/j.anifeedsci.2014.01.018

Romero, C., Medina, E., Vargas, J., Brenes, M., \& De Castro, A. (2007). In vitro activity of olive oil polyphenols against helicobacter pylori. Journal of Agricultural and Food Chemistry, 55(3), 680-686. https://doi.org/10.1021/jf0630217

Romero-García, J. M., Niño, L., Martínez-Patiño, C., Álvarez, C., Castro, E., \& Negro, M. J. (2014). Biorefinery based on olive biomass. State of the art and future trends. Bioresource Technology, 159, 421432. https://doi.org/10.1016/j.biortech.2014.03.062

Rubio-Senent, F., Rodríguez-Gutíerrez, G., Lama-Muñoz, A., \& Fernández-Bolaños, J. (2012). New phenolic compounds hydrothermally extracted from the olive oil byproduct alperujo and their antioxidative activities. Journal of Agricultre and Food Chemistry, 60, 1175-1186. https://doi.org/10.1021/jf204223w

Ruzzolini, J., Peppicelli, S., Andreucci, E., Bianchini, F., Scardigli, A., Romani, A., La Marca, G., Nediani, C., \& Calorini, L. (2018). Oleu- ropein, the main polyphenol of Olea europaea leaf extract, has an anti-cancer effect on human BRAF melanoma cells and potentiates the cytotoxicity of current chemotherapies. Nutrients, 10(12), 1950. https://doi.org/10.3390/nu10121950

Saleh, E., Morshdy, A. E., El-Manakhly, E., Al-Rashed, S., Hetta, H. F., Jeandet, P., Yahia, R., El-Saber Batiha, G., \& Ali, E. (2020). Effects of olive leaf extracts as natural preservative on retailed poultry meat quality. Foods, 9(8), 1017. https://doi.org/10.3390/ foods9081017

Samuel Samson Mathews, Thirunavukkarasu Mahesh, Penumathsa Suresh Varma, Paul Debayon, \& Maulik Nilanjana. (2008). Akt/FOXO3a/SIRT1-Mediated Cardioprotection by n-Tyrosol against Ischemic Stress in Rat in Vivo Model of Myocardial Infarction: Switching Gears toward Survival and Longevity. Journal of Agricultural and Food Chemistry, 56(20), 9692-9698. https://doi.org/10.1021/jf802050h

Sánchez-Fidalgo, S., De Ibargüen, L. S., Cárdeno, A., \& De La Lastra, C. A. (2012). Influence of extra virgin olive oil diet enriched with hydroxytyrosol in a chronic DSS colitis model. European Journal of Nutrition, 51(4), 497-506. https://doi.org/10.1007/ s00394-011-0235-y

Santini, S. J., Porcu, C., Tarantino, G., Amicarelli, F., \& Balsano, C. (2020). Oleuropein overrides liver damage in steatotic mice. Journal of Functional Foods, 65, 103756. https://doi.org/10.1016/j.jff. 2019.103756

Santos-Buelga, C., \& González-Manzano, S. (2011). Wine and health relationships. A question of moderation? Ciência e Técnica Vitivinicola, 26(1), 33-44.

Sarbishegi, M., Mehraein, F., \& Soleimani, M. (2014). Antioxidant role of oleuropein on midbrain and dopaminergic neurons of substantia nigra in aged rats. Iranian Biomedical Journal, 18(1), 16-22. https://doi.org/10.6091/ibj.1274.2013

Schaffer, S., Müller, W. E., \& Eckert, G. P. (2010). Cytoprotective effects of olive mill wastewater extract and its main constituent hydroxytyrosol in PC12 cells. Pharmacological Research, 62(4), 322-327. https://doi.org/10.1016/j.phrs.2010.06.004

Serra, A., Conte, G., Giovannetti, M., Casarosa, L., Agnolucci, M., Ciucci, F., Palla, M., Bulleri, E., Servili, M., \& Mele, M. (2018). Olive pomace in diet limits lipid peroxidation of sausages from cinta senese swine. European Journal of Lipid Science and Technology, 120(1), 1-12. https://doi.org/10.1002/ejlt.201700236

Serrano, A., Fermoso, F. G., Alonso-Fariñas, B., Rodríguez-Gutierrez, G., Fernandez-Bolaños, J., \& Borja, R. (2017). Olive mill solid waste biorefinery: High-temperature thermal pre-treatment for phenol recovery and biomethanization. Journal of Cleaner Production, 148, 314-323. https://doi.org/10.1016/j.jclepro.2017.01.152

Shamshoum, H., Vlavcheski, F., \& Tsiani, E. (2017). Anticancer effects of oleuropein. Biofactors, 43(4), 517-528. https://doi.org/10. 1002/biof.1366

Siciliano, A., Stillitano, M. A., \& De Rosa, S. (2016). Biogas production from wet olive mill wastes pretreated with hydrogen peroxide in alkaline conditions. Renewable Energy, 85, 903-916. https: //doi.org/10.1016/j.renene.2015.07.029

Silva, A. F. R., Resende, D., Monteiro, M., Silva, A. M. S., Cardoso, S. M., \& Coimbra, M. A. (2020). Application of hydroxytyrosol in the functional foods field: From ingredient to dietary supplements. Antioxidants, 9(12), 1246. https://doi.org/10.3390/antiox9121246

Simonato Barbara, Trevisan Sara, Tolve Roberta, Favati Fabio, \& Pasini Gabriella. (2019). Pasta fortification with olive pomace: 
Effects on the technological characteristics and nutritional properties. $L W T, 114,108368$. https://doi.org/10.1016/j.lwt.2019.108368

Smeriglio, A., Denaro, M., Mastracci, L., Grillo, F., Cornara, L., Shirooie, S., Nabavi, S. M., \& Trombetta, D. (2019). Safety and efficacy of hydroxytyrosol-based formulation on skin inflammation: in vitro evaluation on reconstructed human epidermis model. DARU Journal of Pharmaceutical Sciences, 27(1), 283-293. https: //doi.org/10.1007/s40199-019-00274-3

Suárez, M., Romero, M.-P., Ramo, T., Macià, A., \& Motilva, M.-J. (2009). Methods for preparing phenolic extracts from olive cake for potential application as food antioxidants. Journal of Agricultural and Food Chemistry, 57, 1463-1472. https://doi.org/10.1021/ jf8032254

Sun, W., Wang, X., Hou, C., Yang, L., Li, H., Guo, J., Huo, C., Wang, M., Miao, Y., Liu, J., \& Kang, Y. (2017). Oleuropein improves mitochondrial function to attenuate oxidative stress by activating the Nrf2 pathway in the hypothalamic paraventricular nucleus of spontaneously hypertensive rats. Neuropharmacology, 113, 556566. https://doi.org/10.1016/j.neuropharm.2016.11.010

Svobodova, M., Andreadou, I., Skaltsounis, A. L., Kopecky, J., \& Flachs, P. (2014). Oleuropein as an inhibitor of peroxisome proliferator-activated receptor gamma. Genes and Nutrition, 9(1), 376. https://doi.org/10.1007/s12263-013-0376-0

Tabernero, M., Sarriá, B., Largo, C., Martínez-López, S., Madrona, A., Espartero, J. L., Bravo, L., \& Mateos, R. (2014). Comparative evaluation of the metabolic effects of hydroxytyrosol and its lipophilic derivatives (hydroxytyrosyl acetate and ethyl hydroxytyrosyl ether) in hypercholesterolemic rats. Food and Function, 5(7), 1556-1563. https://doi.org/10.1039/c3fo60677e

Takeda, Y., Bui, V. N., Iwasaki, K., Kobayashi, T., Ogawa, H., \& Imai, K. (2014). Influence of olive-derived hydroxytyrosol on the toll-like receptor 4-dependent inflammatory response of mouse peritoneal macrophages. Biochemical and Biophysical Research Communications, 446(4), 1225-1230. https://doi.org/10.1016/j.bbrc.2014.03.094

Tayeh, H., Najami, N., Dosoretz, C., Tafesh, A., \& Azaizeh, H. (2014). Potential of bioethanol production from olive mill solid wastes. Bioresource Technology, 152, 24-30. https://doi.org/10. 1016/j.biortech.2013.10.102

Tejada, S., Pinya, S., del Mar Bibiloni, M., Tur, J. A., Pons, A., \& Sureda, A. (2016). Cardioprotective effects of the polyphenol hydroxytyrosol from olive oil. Current Drug Targets, 18(13), 14771486. https://doi.org/10.2174/1389450117666161005150650

Tu, P., Song, Z. \& Lei, L. (2005). Patent EP 1498131 A1. Medicinal preparation containing phenylethanoid glycosides extracted from Cistanche tubulosa. Issued March 19, 2014.

Valenti, F., Arcidiacono, C., Chinnici, G., Cascone, G., \& Porto, S. M. (2017). Quantification of olive pomace availability for biogas production by using a GIS-based model. Biofuels, Bioproducts and Biorefining, 11, 784-797. https://doi.org/10.1002/bbb.1784

Vertuani, S., Beghelli, E., Scalambra, E., Malisardi, G., Copetti, S., Toso, R. D., Baldisserotto, A., \& Manfredini, S. (2011). Activity and stability studies of verbascoside, a novel antioxidant, in dermocosmetic and pharmaceutical topical formulations. Molecules, 16(8), 7068-7080. https://doi.org/10.3390/molecules16087068

Vilaplana-Pérez, C., Auñón, D., García-Flores, L. A., \& Gil-Izquierdo, A. (2014). Hydroxytyrosol and potential uses in cardiovascular diseases, cancer, and AIDS. Frontiers in Nutrition, 1, 18. https://doi. org/10.3389/fnut.2014.00018
Villanova, L., Villanova, A., Villanova, L., Merendino, A., Fasieloo, G. \& Cisale, F. (2010). US Patent 2010/0297330 A1 Yoghurt containing hydroxytyrosol and other biophenols with a preventive nutritional activity beneficial to human beings. November 25, 2010.

Xia, D., Zhang, Z., \& Zhao, Y. (2018). Acteoside attenuates oxidative stress and neuronal apoptosis in rats with focal cerebral ischemiareperfusion injury. Biological and Pharmaceutical Bulletin, 41(11), 1645-1651. https://doi.org/10.1248/bpb.b18-00210

Xie, P., Huang, L., Zhang, C., Deng, Y., Wang, X., \& Cheng, J. (2019). Enhanced extraction of hydroxytyrosol, maslinic acid and oleanolic acid from olive pomace: Process parameters, kinetics and thermodynamics, and greenness assessment. Food Chemistry, 276(16), 662-674. https://doi.org/10.1016/j.foodchem.2018.10.079

Xu, F., Li, Y., Zheng, M., Xi, X., Zhang, X., \& Han, C. (2018). Structure properties, acquisition protocols, and biological activities of oleuropein aglycone. Frontiers in Chemistry, 6, 239. https://doi.org/10. 3389/fchem.2018.00239

Yakhlef Wahiba, Arhab Rabah, Romero Concepción, Brenes Manuel, de Castro Antonio, \& Medina Eduardo. (2018). Phenolic composition and antimicrobial activity of Algerian olive products and byproducts. $L W T$, 93, 323-328. https://doi.org/10.1016/j.lwt.2018.03. 044

Zbakh, H., \& El Abbassi, A. (2012). Potential use of olive mill wastewater in the preparation of functional beverages: A review. Journal of Functional Foods, 4(1), 53-65. https://doi.org/10.1016/j.jff.2012. 01.002

Zbidi, H., Salido, S., Altarejos, J., Perez-Bonilla, M., Bartegi, A., Rosado, J. A., \& Salido, G. M. (2009). Olive tree wood phenolic compounds with human platelet antiaggregant properties. Blood Cells, Molecules, and Diseases, 42, 279-285. https://doi.org/10.1016/ j.bcmd.2009.01.001

Zhang, J., Nugrahaningrum, D. A., Marcelina, O., Ariyanti, A. D., Wang, G., Liu, C., Wu, S., \& Kasim, V. (2019). Tyrosol facilitates neovascularization by enhancing skeletal muscle cells viability and paracrine function in diabetic hindlimb ischemia mice. Frontiers in Pharmacology, 10, 909. https://doi.org/10.3389/fphar.2019. 00909

Zhao, Q., Bai, Y., Li, C., Yang, K., Wei, W., Li, Z., .., \& Zhang, X. (2017). Oleuropein protects cardiomyocyte against apoptosis via activating the reperfusion injury salvage kinase pathway in vitro. Evidence-Based Complementary and Alternative Medicine, 2017, 2109018. https://doi.org/10.1155/2017/2109018

Zoidou, E., Melliou, E., Moatsou, G., \& Magiatis, P. (2017). Preparation of functional yogurt enriched with olive-derived products. In N. Shah (Ed.), Yogurt in health and disease prevention (1st ed., pp. 203-220). Elsevier Inc. https://doi.org/10.1016/B978-0-12-805134-4. 00011-0

How to cite this article: Madureira, J., Margaça, F. M. A., Santos-Buelga, C., Ferreira, I. C. F. R., Cabo Verde, S., \& Barros, L. (2021). Applications of bioactive compounds extracted from olive industry wastes: A review. Compr Rev Food Sci Food Saf, 1-24. https://doi.org/10.1111/1541-4337.12861 


\section{Meet the Microbes: The Role of Microorganisms in the Safety, Quality, and Shelf life of Meat and Meat Products}

\section{Free Virtual Seminar | December 2, 2021 | 12PM EST}

Microorganisms in meat play a significant role in the safety, quality, and shelf life of meat and meat products. Pathogenic organisms such as Salmonella, E.coli 0157:H7, Campylobacter, and Listeria monocytogenes represent important food safety hazards and public health threats. Other microorganisms are involved in spoilage, quality issues, and reduced shelf life.

In this webinar, we will explore major pathogens in meat and the public health burden of foodborne illness outbreaks involving these pathogens, issues dealing with sampling and the microbiological testing of meat, and industry and regulatory approaches for assuring the safety and quality of meat and meat products. We will also discuss the 25th anniversary of HACCP regulation for meat and meat products, and its impact on meat safety.

\section{Register here}

\section{Food Safety}

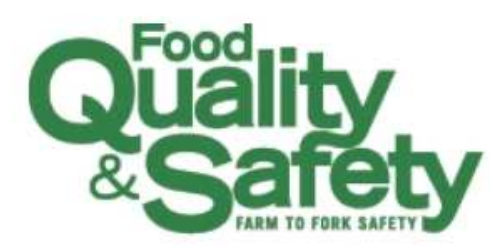

